Geological Society Special Publication 451, 2017. https://doi.org/10.1144/SP451.5 as published by Geological Society of London (c) Geological Society of London, 2017. 


\section{Radon as a Carcinogenic Built-Environmental Pollutant.}

Gavin K. Gillmore ${ }^{1 *}$

Robin G. M. Crockett ${ }^{2}$

robin.crockett@northampton.ac.uk

Paul S. Phillips ${ }^{2}$

pauls.phillips@icloud.com

${ }^{* 1}$ Corresponding author. School of the Natural and Built Environment, Kingston University, KT1 $2 E E$.

${ }^{2}$ Department of Environmental and Geographical Sciences, School of Science and Technology, University of Northampton, NN2 6JD. 


\section{Abstract}

Radon $\left({ }^{222} \mathrm{Rn}\right)$ has been highlighted by a number of authors as a significant public health concern. For example, it is the second most significant cause of lung cancer after tobacco smoking (ca. 1,000-2,000 and 21,000 deaths per year in the UK and USA respectively; US EPA, 2003; Darby et al., 2005; Dixon, 2006; HPA, 2009), yet a very high proportion of the general public appears to be unaware of the risk. This chapter deals with topical radon issues such as radon in the workplace; radon in homes; exposure to radon during leisure activities; radon and water; measurement and monitoring; seasonal correction; remediation; cancer risks; cost-benefit analysis and costeffectiveness; mapping; future policies; and further research. This assessment of the state of radon research is focused on the UK as an example of a country where radon has been on the governmental agenda since the late 1970s, but also highlights radon issues throughout the world in, for example, the USA, Europe and Asia.

\section{Highlights}

1. Radon- an issue in the home, workplace and during leisure activities.

2. Evaluation of indoor radon hazard.

3. Aspects of measurement, monitoring and remediation.

4. The future for radon research and policy.

\section{Key Words}

Radon, built environment, cancer, carcinogen, dose, exposure. 


\section{Introduction and Overview}

Radon is a colourless and odourless naturally occurring radioactive noble gas. Radon has a number of isotopes but only two, i.e. ${ }^{222} \mathrm{Rn}$ ('radon') and ${ }^{220} \mathrm{Rn}$ ('thoron'), are thought to pose any threat to human health (Cliff and Gillmore, 2001). Of these, ${ }^{222} \mathrm{Rn}$ (plus its progeny) poses the greater risk to health as it accounts for approximately $50 \%$ of the average radiation dose to a member of the public per year (Figure 1). The average human exposure to natural radiation sources worldwide is $2.4 \mathrm{mSv}$ per year (UNSCEAR, 1988; Little, 2003).

The reasons for this are linked to the half-lives: ${ }^{222} \mathrm{Rn}$ has a half-life of 3.825 days, and is part of the ${ }^{238} \mathrm{U}$ decay chain (see Figure 2), whereas ${ }^{220} \mathrm{Rn}$ has a half-life of 55.6 seconds, and is part of the ${ }^{232} \mathrm{Th}$ decay chain. This three orders of magnitude difference in half-life means that higher proportions of ${ }^{222} \mathrm{Rn}$ are able to diffuse out of the ground into the air and accumulate in spaces in the natural and built environments before undergoing radioactive decay. This, in turn, means that higher proportions of ${ }^{222} \mathrm{Rn}$ are available for inhalation by humans and animals, and it is the inhalation of the radioactive nuclei which poses the lung cancer risk. The concentration of ${ }^{220} \mathrm{Rn}$ in room air accounts on average for approximately $4 \%$ of the total annual radiation dose received by a member of the public in the UK.

The average ${ }^{222} \mathrm{Rn}$ levels in homes in the $\mathrm{UK}$ is $20 \mathrm{~Bq} \mathrm{~m}^{-3}$ (see Watson et al., 2005) which gives an average effective dose for an individual from this source of $1 \mathrm{mSv}$ per year. Average levels in other European countries vary from $23 \mathrm{~Bq} \mathrm{~m}^{-3}$ (the lowest but one average value in Western Europe; see Stoop et al., 1998) for the Netherlands to $84 \mathrm{~Bq} \mathrm{~m}^{-3}$ for Finland (geometric mean; Radiation Protection Authorities in Denmark, Finland, Iceland, Norway and Sweden, 2000). For further European examples see Table 1. In the USA, radon levels vary significantly from state to state, but the Environmental Protection Agency (EPA) suggests that the average indoor radon level for the whole of the USA is $48 \mathrm{~Bq} \mathrm{~m}^{-3}\left(1.3 \mathrm{pCi} \mathrm{L}^{-1}\right)$. Utah has an average indoor radon level of 174 $\mathrm{Bq} \mathrm{m}^{-3}\left(4.7 \mathrm{pCi} \mathrm{L}^{-1}\right)$ based on short-term measurements of 6,000 homes while Texas has an average concentration of $37 \mathrm{~Bq} \mathrm{~m}^{-3}\left(1 \mathrm{pCi} \mathrm{L}^{-1}\right)$ but with highs exceeding $740 \mathrm{~Bq} \mathrm{~m}^{-3}\left(20 \mathrm{pCi} \mathrm{L}^{-1}\right)$ in the Panhandle area (Smith et al., 1994). By way of contrast, the geometric radon mean for Australian homes is $8 \mathrm{~Bq} \mathrm{~m}^{-3}$ (Langroo et al., 1990). The world average (population-weighted) radon concentration is $40 \mathrm{~Bq} \mathrm{~m}^{-3}$ (UNSCEAR, 2009).

The interaction between radon and human health has, to a large extent, only been studied in the last 50 or so years (Cliff and Gillmore, 2001). During the 1960s, in Colorado, waste from uranium 
ore processing had been used to back-fill around the basements of certain homes. These homes were subsequently found to have significantly raised indoor ${ }^{222} \mathrm{Rn}$ levels because ${ }^{222} \mathrm{Rn}$ had diffused from the tailings through the basement walls and floors into the dwelling spaces. As a result of this, the US Surgeon General advised the Colorado State Department of Health in 1970 that there should be a limit to the radon concentration in indoor air and that action should be taken to reduce the levels of radon and its decay products above that limit. The US EPA has since set an action level for $\mathrm{a}^{222} \mathrm{Rn}$ concentration averaged over a year of $148 \mathrm{~Bq} \mathrm{~m}^{-3}\left(4 \mathrm{pCi} \mathrm{L}^{-1}\right)$. They have also stated that ${ }^{222} \mathrm{Rn}$ levels should be reduced as soon as possible in homes with radon levels above $2 \mathrm{kBq} \mathrm{m}^{-3}$. It is interesting to note that in 1984, a construction engineer working on the Limerick Nuclear Power Plant near Philadelphia, USA, was the source of radioactive contamination that was setting off the alarms as he entered work (Cliff and Gillmore, 2001). On investigation, it was discovered that this engineer was living in a house built on a geological formation known as the Reading Prong area of Pennsylvania which is known to contain narrow veins of high grade uranium ore, which are widely spaced and not economically exploitable, and the ${ }^{222} \mathrm{Rn}$ levels in the house were 130 times the US Federal occupational standard for uranium miners (Cliff and Gillmore, 2001). More generally in the Reading Prong area, $40 \%$ of the homes were estimated to have ${ }^{222} \mathrm{Rn}$ levels above the USA EPA Action Level (the level at which it is deemed cost-effective to remediate homes in order to reduce the risk of radon-induced lung cancers; US EPA, 2003).

As the result of an EPA survey which demonstrated that around 5-6\% of US homes (5.8 million) exceeded the Action Level, the EPA set a target of 20 million homes to be tested by the year 2000 . Table 2 highlights US radon policies and their development together with various organisations concerned with radon issues. As a result of recent US housing booms there are now more homes with elevated radon concentrations than ever before, with an estimated $88 \%$ of Americans not knowing that radon is the second leading cause of lung cancer (see the Federal Radon Action Plan, 2011 and Healthy People 2020 targets, 2010), and many low- and middle- income US families are either not willing to or cannot afford to fund radon mitigation for their homes.

In the UK, the National Radiological Protection Board (NRPB), now part of Public Health England (PHE), was established in 1971. In 1976 the NRPB surveyed a limited number of homes and followed this with a much more substantial survey in 1981 which showed that 2,093 dwellings had an average ${ }^{222} \mathrm{Rn}$ level of $20 \mathrm{~Bq} \mathrm{~m}^{-3}$, but the highest level recorded was $1 \mathrm{kBq} \mathrm{m}^{-3}$. Subsequent regional surveys, however, found a high value of $10 \mathrm{kBq} \mathrm{m}^{-3}$ in a home in Cornwall, with Cornwall and Devon having an average value of $300 \mathrm{~Bq} \mathrm{~m}^{-3}$ in homes (Cliff and Gillmore, 2001). Recent studies have shown that concentrations of $17 \mathrm{kBq} \mathrm{m}^{-3}$ have been found in one home in the south 
west of England (Watson et al., 2005; Rees et al., 2009). It is interesting to note that there are uranium ores such as pitchblende and uraninite associated with polymetallic ore mineralisation in the south west of England, and these have certainly contributed to raised radon levels (Gillmore et al., 2001). Varley and Flowers (1998) suggested that the metamorphic aureole around the granite areas of Cornwall and Devon has a significant impact on indoor radon levels. In 1987 the NRPB recommended an Action Level of $400 \mathrm{~Bq} \mathrm{~m}^{-3}$ for domestic dwellings (annual average radon level; NRPB, 1987), but this was reduced to $200 \mathrm{~Bq} \mathrm{~m}^{-3}$ in 1990 (NRPB, 1990) after reassessing the risks of radiation exposure. In 1990, the concept of Radon Affected Area (RAA) was introduced, being defined as an area with a $1 \%$ or greater probability of homes being above the Action Level (Cliff and Gillmore, 2001). The first RAAs identified were Cornwall and Devon (Miles et al., 1990). By 1997 in the UK, around 350,000 homes had been tested (Cliff and Gillmore, 2001). This figure rose to over 450,000 by 2003 (Miles, 2003b), reaching 500,000 by 2007 (ENHIS, 2007). An interesting development is that the UK Health Protection Agency (HPA, now PHE) in 2009 highlighted that the majority of UK radon-induced lung cancer deaths do not occur in RAAs: most are associated with domestic radon concentrations of less than $200 \mathrm{~Bq} \mathrm{~m}^{-3}$ with $70 \%$ associated with levels below $50 \mathrm{~Bq} \mathrm{~m}^{-3}$. Table 3 illustrates radon policies and their development, together with organisations concerned with radon issues, for the UK (including Northern Ireland) and the Republic of Ireland. In the Republic of Ireland, high radon levels have been noted by Organo et al. (2004; also Gillmore et al., 2005a; Ellard, 2006) with, for one house, average radon concentrations greater than $50 \mathrm{kBq} \mathrm{m}^{-3}$. That house was occupied for a number of years by a couple with a daughter and, unfortunately, both parents (lifelong non-smokers) have died of lung cancer and the daughter (also a non-smoker) has been diagnosed with lung cancer.

It is important to stress that studies worldwide all demonstrate that radon concentrations vary considerably within and between homes both spatially and temporally. Where the Irish example above is concerned it has been suggested that radon concentrations in the region vary considerably due to the karstic limestone on which homes in the region are built - and the way in which radon saturated groundwater can move from cave to cave (see Gillmore et al., 2005a). The EPA in the USA, the Radon Council in the UK as well as others (e.g. see Cliff and Gillmore, 2001; Papworth, 1997) have indicated that the only way to be certain that a specific property does not have a radon problem is to test it: prediction on the basis of other evidence is not a fail-safe alternative. Radon concentrations can vary so much that it would be good practice to repeat a test if conditions in the home change, particularly in RAAs, due, for example, to the addition of double glazing, or central heating or structural changes. 


\section{Radon Distribution in the Environment}

\subsection{Geology and distribution of uranium and radium in rocks and soils.}

In the study undertaken by Gunby et al. (1993), underlying rock characteristics of over 2,000 homes in the UK were classified into 22 categories. Within their rock type factor, the largest increase in indoor radon was due to the presence of 'Granite 1'. This is the type of granite that is found in the South West of England in Devon and Cornwall. This factor had the largest effect on radon concentrations in the home, in the study, and by a considerable margin. Other authors similarly highlighted the significance of underlying geology in influencing indoor radon concentrations (e.g. Gundersen and Peake, 1992). In the UK raised indoor radon has been associated with granites, black shales, phosphatic rocks and ironstones, limestones and associated shales and cherts, certain sands and sandstones and greywackes together with superficial Quaternary deposits (see Appleton et al., in press).

The relationship between underlying geology and indoor radon then is complicated (Gundersen and Peake, 1992; Gillmore et al., 2001; Gillmore et al., 2005a). Indoor radon concentrations can be said to be dependent on climate, bedrock composition, permeability of the soil and soil texture as well as on house construction, type and life style of occupants.

Wysocka (2003) produced a study in Silesia, Poland of radon concentrations on various geological rock types, such as Triassic limestones and dolomites (which outcrop in the south-east of Silesia), Carboniferous strata and Tertiary to Quaternary deposits (the latter occurs to a depth of 10 metres in places). Wysocka (2003) noted that radon concentrations could be directly related to the underlying geology and the existence of past mining. The average radon concentration in Upper Silesia at ground floor level was $47 \mathrm{~Bq} \mathrm{~m}^{-3}$, while in the cellars it was $64 \mathrm{~Bq} \mathrm{~m}^{-3}$. The highest radon concentrations were noted on the dolomites and limestones and there were significant variations within the coal-basin region. The most radon prone geological horizon was a layer of Muchelkalk which was strongly fissured with solutional features such as caverns that acted as pathways for radon gas. Using geophysical survey techniques, Wysocka (2003) was able to identify areas where significant mining activity had led to underground collapse and activation of fault zones, and which gave rise to high average radon concentrations at the surface. These zones of raised radon concentrations were in areas mined either at depth for coal or at shallow depths for metallic ore. This meant that geological layers that may not normally give rise to raised radon concentrations in homes might do so if earlier mining activity had taken place (see also comments on mined ground 
by Appleton et al., (in press). The highest radon concentrations measured were in weathered leadzinc ore-bearing dolomites in a geological fault zone. It is quite likely that some raised radon concentrations in some localised areas in the UK may also be the result of previous mining activity and similar collapses. It is interesting to note that in Derbyshire, in the UK, lead ore veins can be followed by examining the radon concentrations in overlying homes.

In the UK, PHE bases its advice on whether to measure for radon in houses or workplaces partly on radon-potential maps that are constructed from a database maintained by the British Geological Survey. There are several studies that demonstrate that radon risk maps based on geology may, at times not be reliable indicators of radon concentrations in homes (see Hulka et al., 1997; Miles, 1998). In 1993, Gunby et al. suggested that there were not enough data in sufficient detail available across the UK to allow for the variation in geology to be appropriately taken into account when assessing the likely concentration of radon in a building. Miles (1998) suggested that a detailed investigation of indoor radon measurements is necessary before reasonably accurate radon-potential maps can be drawn up. In south-west England there is on average 15 house measurements per kilometre grid square (Miles, 2003a). In some regions of the UK, which has a diverse terrain, there are some areas which are empty of habitation and therefore no radon results are available. The danger therefore of relying on radon potential maps is that new houses may be built in areas that lead to high radon concentrations because of a lack of previous data. The recently revised BGS/PHE radon potential map has gone some way towards addressing this issue (see details of methodology in Appleton et al., in press). In a Building Research Establishment (BRE) report (BR211, 1999), two sets of maps are presented. One set shows geologically-based radon-potential maps the other radon test based maps. The recommendation is that these maps should be used together when deciding whether protective measures should be put in place when building a new home. Such maps group radon results by kilometre grid squares and an estimate is made of the percentage of homes above the Action Level. The square is then coloured accordingly. Results on the geologically based radon maps are grouped by geological 'units'. One problem with such maps is that grid squares cross important geological boundaries. It may be just part of a geological formation that is an issue for radon, not the whole formation. Radon potential can vary by a factor of 10 across a geological unit (Miles, 2003a). Hall (2003) suggested that radon measurements in Scotland were insufficient for the construction of a radon-potential map similar to that in England possibly due in part to complex underlying geology, although a new map was published by Green $e t$ al. (2009).

Peart et al. (2003) reported the results of an airborne geophysical survey, HiRes-1 (High Resolution airborne Resource and Environmental Survey: Phase 1) that can be related to potential 
radon, acquired in 1998. This survey covered 14,000 $\mathrm{km}^{2}$ of central England and included gamma spectrometry. HiRes-1 mapped relatively high uranium concentrations associated with Carboniferous Limestones (Dinantian) and overlying Carboniferous (Namurian) Shales. The project also mapped the Lower Jurassic Marlstone Rock Formation near Melton Mowbray and the Lincolnshire Limestone Formation which were both found to yield high thorium counts. Figure 3 illustrates the general distribution of relatively high uranium count variability between the various limestone horizons (Peart et al., 2003). Figure 4 highlights variability in one of the Dinantian horizons, the Bee Low Formation. The highest uranium concentrations in the latter occur along the western edge of the Formations which reflect the apron reef limestone facies. Elsewhere, the lowest values indicate where the limestone has been quarried out. Figure 5 from Peart et al. (2003) shows the distribution of thorium variability in the Jurassic Marlstone Formation. The hatched zones are areas that have been mined and backfilled. These areas show the highest thorium values. The Dinantian Limestones of the Peak District, the Lincolnshire Limestone and Marlstone Rock Formations are all well known to be associated with higher indoor radon concentrations (Peart $e t$ al., 2003; BGS Geohazard Note, 2012). The Marlstone Rock Formation also contains (as well as raised thorium content) raised uranium concentrations, with uranium around $2.56 \mathrm{ppm}$ (range 1.17 $5.40 \mathrm{ppm}$ ) and an average ${ }^{226} \mathrm{Ra}$ activity of $33.1 \mathrm{~Bq} \mathrm{~kg}^{-1}$ (range $11.5-83.0 \mathrm{~Bq} \mathrm{~kg}^{-1}$ ) (see Scheib et al., 2013). Authors such as Peart et al. (2003) argue that such airborne radiometric techniques have the potential to be an efficient tool for rapid mapping of variation in radon potential. This method certainly has the potential to delineate variation within geological units. However, it does not necessarily take into account the mobility of certain uranium species which can be transported by water, the impact that fluctuating groundwater levels may have on indoor radon levels, the slope of a site, the porosity of the underlying geology and seasonal variation.

New surveys have been conducted in recent years using ground geochemical methods combined with airborne geophysical surveying which is producing interesting results (for example Tellus Ireland and Tellus Border completed in 2007 and 2012, together with a newer development, Tellus SW; see Tellus SW Geophysical Survey factsheet, 2013).

It was in mines that the first detailed surveys of ${ }^{222} \mathrm{Rn}$ concentrations were carried out in the UK (see Boyd et al., 1970). Such surveys began in the 1960s and by the end of 1974 some 53 active mines had been assessed (Duggan et al., 1968; Strong et al., 1975). It was not until the introduction by the UK government of the Ionising Radiation Regulations (IRR, 1985; updated by IRR 1999), however, that exposure of all miners/workers to radon and its daughters was brought under regulatory control. Muirhead et al. (1993) clearly demonstrated that high radon concentrations 
caused lung cancer in mine workers. Lubin et al. (1995) examined a data set comprising of 65,000 miners and 2,700 lung cancer deaths. They suggested from extrapolation that exposures at the concentrations found in homes carried some risk. Field and Becker (2001) suggested that of the 20 or so epidemiological studies of miners exposed to radon underground that have been undertaken to date, 11 have 'provided exposure response relationships between radon and progeny exposure and lung cancer'.

\subsection{Exposure to radon in the natural environment: show caves and mines.}

For the purposes of legislation caves and mines are included as workplaces (see section 4.5) when they are open to the fee paying public and, as enclosed spaces in the natural environment, have many radon concerns in common with the built environment. Gillmore et al. (2000a and b; 2001 ; 2002) demonstrated that ${ }^{222} \mathrm{Rn}$ has complex modes of transport and dispersion in caves and mines, with accumulation taking place in localised areas of stationary air when ventilation is poor. Gillmore et al. (2000a) established a theoretical perspective on the geological and speleological factors which influence radon concentrations. Factors that need to be considered include subterranean streams, airflow, cave morphology, faults, lithology and weathering.

In several areas of the UK, cave systems are sufficiently accessible to the general public and of sufficient interest for them to be tourist attractions. Such show caves have to install air ventilation systems (Phillips, 1995) to control radon concentrations. These caves are subject to IRR (1999) and are monitored and regulated by the HSE or local Environmental Health Officers to ensure satisfactory conditions to protect workers. Gillmore et al. (2002) undertook a study of radon concentrations in Creswell Crags in Derbyshire. This cave system contains a show cave. Gillmore et al. (2002) were able to show that the visitors to the show cave were not at risk from raised concentrations and neither were the guides. However, archaeologists or earth scientists working in the more inaccessible parts of the show cave would be at risk if they spent any appreciable amount of time there due to raised radon levels of around $3 \mathrm{kBq} \mathrm{m}^{-3}$ in those parts where ventilation was poor.

Gillmore et al. (2000a, b) demonstrated that recreational and occupational cave users could be at risk due to elevated radon concentrations. Gillmore et al. (2000a, b, 2001) noted mean radon concentrations in one part of one cave of over $12 \mathrm{kBq} \mathrm{m}^{-3}$ in the Mendips in the UK. They suggested that a casual caver who had 10 trips down such a cave, with around 40 hours underground in total, would have received a dose of around $4 \mathrm{mSv}$ per year (four times the average 
yearly dose maximum suggested by the ICRP for a member of the public). The occasional (sports) caver would have a potential dose of $12 \mathrm{mSv}$ while the occupational caver (or cave guide) might have a dose of $120 \mathrm{mSv}$ per year. Comparing this to the IRR Action Level of $400 \mathrm{~Bq} \mathrm{~m}^{-3}$ for a worker ( 8 hours per day, over 200 days per year) which equates to $5 \mathrm{mSv}$, it can be seen that regular recreational users and cave guides in high radon concentration environments are putting themselves at notable risk from radon (Gillmore et al., 2000a,b; 2001).

There are also many caves visited by members of the public in the UK and abroad, including parts of the world where there are no legislative controls, that are not show caves and such caves can have considerable radon concentrations and be a serious health hazard.

Even higher radon concentrations have been discovered in abandoned mines in the UK. Gillmore et al. (2001) reported concentrations as high as $7.1 \mathrm{MBq} \mathrm{m}^{-3}$ in abandoned metalliferous mines in Devon, Southwest England. This was 89 times higher than the highest published radon level for caves and mines in Devon and Cornwall (Gillmore et al., 2001). Gillmore et al. (2001) calculated that the casual mine explorer (defined as having 10 trips, accruing 20 hours underground) would have a dose level of $348 \mathrm{mSv}$ in one mine taking into consideration averaged radon levels. The mine explorer (30 trips and 60 hours) would have received a dose equivalent of $1,045 \mathrm{mSv}$, while the occupational explorer (300 trips, 600 hours accrued) would have a dose of 10,447 mSv. These doses are extremely high and pose a very significant health risk.

Radon concentrations in caves around the world vary. Solomon et al. $(1992,1996)$ noted radon levels of $6,300 \mathrm{~Bq} \mathrm{~m}^{-3}$ in some Australian show caves, giving average yearly effective dose ranges from 0.08 to $2.8 \mathrm{mSv}$ for tour guides. The well-studied large cave system of South Central Kentucky, USA, demonstrates substantial variations in radon concentrations, i.e. a range of 2,3904,490 Bq m${ }^{-3}$, with a mean of 3,100 Bq m${ }^{-3}$ (Eheman et al., 1991). Hyland and Gunn (1994) in their survey of $47 \mathrm{UK}$ caves suggested a mean radon concentration of $8,868 \mathrm{~Bq} \mathrm{~m}^{-3}$.

Lastly, there are radon spas, caves, tunnels and mines in many European countries, e.g. Hungary, Germany, Czech Republic, Austria, and also the USA, for which health benefits are claimed for exposure to radon, i.e. claim that exposure to radon in the air and water in such places is beneficial to health, therapeutic, curative (e.g. see Szerbin, 1996; Becker, 2003; Erickson, 2007; and also Girault et al., 2016 (this volume), with regard to springs and spas). This is in direct opposition to advice from the World Health Organisation (WHO, 1988 \& 2009), BEIR (1999), etc. that no exposure to radon, or any other ionising radiation, can be considered safe. We do not discuss the 
claimed benefits here but simply note that such places exist for those people who choose to expose themselves to radon (and radioactive daughters) despite the overwhelming body of information that to do this increases the risk of lung and possibly other cancers.

\subsection{Anthropogenic Radon}

So far, we have only considered radon as naturally occurring and arising in the natural environment and entering and accumulating in the built environment. However, current research at Kingston and Northampton Universities in the UK is indicating that significant radiological hazard can arise from radon emanating from radioluminescent paints, such as used in clocks and watches and other equipment having luminous dials and pointers and, potentially, uranium- and radiumcontaining ornaments and artefacts. Equipment containing radioluminescent paints continued to be produced until the 1960s, when production was banned in the US, UK and most of Western Europe.

In 1977 the US National Council on Radiation Protection and Measurements published a report (NCRP, 1977) on radiation exposure from consumer products. This report commented specifically on radiation dose from radioluminescent paints, in particular watch and clock dials. Boerner and Buchholz (2007), updated that report in 2007 with a scoping study for the US Nuclear Regulatory Commission (NRC). Shaw et al. (2007) have also recently produced guidelines for European Union countries regarding the control of consumer products containing radioactive materials.

Radium-dial watches and clocks and other similar ex-military items are still in circulation, having become collectors' items in their own right (Boerner and Buchholz, 2007). The paints used varied in composition amongst manufacturers but all consist of crystalline phosphorescent zinc sulphide $(\mathrm{ZnS})$ with the addition of radium $\left({ }^{226} \mathrm{Ra}\right.$, half-life 1600 years $)$ and/or mesothorium $\left({ }^{228} \mathrm{Ra}\right.$, half-life 5.8 years) and/or radiothorium $\left({ }^{228} \mathrm{Th}\right.$, half-life 1.9 years $)$ in the form of insoluble sulphates (Martland and Humphries, 1973).

However, some collectors and other handlers of such items are unaware of the dangers of radioluminescent materials and even those who are aware of the radiation risk directly arising from the radium etc. in the paints are unaware of the risk arising from the radon generated from the radioactive decay of the radium and which emanates from watches with no or damaged/deteriorated seals. The amounts of radioactivity arising from both the paint and the radon will depend on the manufacturer, specific materials used, age and condition of the watch or clock, etc. but, in general, ex-military equipment produces ambient equivalent dose rates two or more times that of broadly 
equivalent civilian equipment. This is an important consideration because ex-military equipment, e.g. as sold to the public as surplus stock after the Second World War, is now highly collectable and sought-after by collectors.

The HSE (2002) highlighted controls on timepieces containing radioluminescent materials for those in the retail and antique trade, noting that they were no longer free to dispose of damaged items with general refuse (96/29/EURATOM). Whilst Shaw et al. (2007) noted that regulation of radium timepieces or 'historic products' sold in antique markets and the Internet was 'impossible', they also suggested that the number of such products still in circulation was 'assumed to be very small': whilst this is true in absolute terms compared to the numbers produced, it could be a misleading assumption in some circumstances as such items are commonly available on Internet auction sites such as eBay.

The radon emissions from radium paint have remained relatively less known (although it has been recognised that radon in working environments was a concern for radium dial painters; Bruenger et al., 1994) and understood than the radium itself and thus are potentially of more concern, particularly to collectors of radioluminescent and other uranium and radium containing articles. The risk to themselves will depend on the time they spend with their collections, as well as the amounts of radioactive material in their collections, but collectors also have a duty of care for the risk to any visitors, particularly visitors who are not fellow collectors.

As described by Gillmore et al. (2012), conservative and precautionary measurements of radon arising from a notional collection of 33 radium-dial watches and a couple of miscellaneous items indicate that radon concentrations routinely exceed the UK HPA/NRPB Domestic Action Level of $200 \mathrm{~Bq} \mathrm{~m}^{-3}$ in a ventilated laboratory environment, rising to over 10 times that Action Level at lower ventilation rates. This led to the conclusion that private collectors, who might typically keep their collections in (small) rooms in houses (possibly secured and/or unventilated and/or in sealed cabinets) will potentially expose themselves to very high concentrations of radon, particularly when in the proximity of their collections. A further complication is that radon emanating from radioluminescent paints will neither necessarily follow the 'standard' domestic spatial distribution nor vary according to the 'standard' seasonal variations and so a 'standard' radon measurement (with seasonal correction) might yield misleading or erroneous results. Results of a follow-up study of radon emissions from radium-dial watches are included in this volume. 


\section{Radon, Cancer and Risk.}

\subsection{Radon as a cause of lung cancer}

Rothstein (2003a) said the radon issue 'induces only eye-rolling ennui' in the public, despite the fact that we live in a world that seems to be highly focused on risks and their management.

Rothstein (2003a) suggested that the general population do not even like to think about the potential health risks from radon. However, the evidence that radon can cause lung cancer is overwhelming (see Darby et al., 2005). When radon is inhaled, short-lived radioactive progeny (polonium, lead and bismuth) are deposited on surfaces in the respiratory tract. The bronchial epithelium may then receive a significant dose from alpha irradiation. Heavy particles such as alpha particles lead to densely ionising radiation damage in a concentrated pattern causing deletion or reordering of chromosomal DNA (Hande et al., 2003). Published data shows that radon is the second largest cause of lung cancer (Dixon, 2001) and may be responsible for 3-6\% of lung cancer deaths in the UK (see also Green et al., 1992). Wichmann et al. (2002) suggested that $7 \%$ of all lung cancers in Germany could be due to indoor radon. This view of radon as a significant risk is extensively supported in the scientific literature (see ICRP, 1984, 1987; WHO, 1988, 2009).

Quantifying risk from radon is not always straightforward because of other environmental factors such as smoking (the largest cause of lung cancer deaths in the UK; see Spear 2000). However, it is possible for case-control epidemiological studies to take account of smoking according to Field (Field and Becker, 2001). Some authors have gone so far as to suggest that even the radon exposure limits set by most governments imply a level of risk that would not be accepted for other hazards (e.g. Rothstein, 2003a, b). Dixon (2001) indicated that this risk is larger than many that prompt a high level of concern and subsequent action to reduce that risk.

It is important to recognise that there are some authors that suggest that the risks from radon have been over-emphasised (see comments by Becker in Field and Becker, 2001). Some authors have suggested that epidemiological data does not reliably reveal an association between high radon concentrations and any above-normal incidences of lung cancer (see discussions in Lubin and Boice, 1997). Cohen (1989) has even suggested that low-levels of radon may be beneficial to health, although some have questioned the methodology used by Cohen (see Lubin et al., 1997; Darby et al., 1998). Samavat (2002) in a study in high level natural radiation areas in Iran went so far as to suggest that perhaps doses of 5-20 mSv per year may not increase cancer incidents but may have a positive effect in terms of resistancy in the population exposed. Samavat (2002) described 
his work as having an epidemiological approach but was in fact essentially ecological after the definition of Miles (2003a). In contrast, recent epidemiological studies that have clearly demonstrated a link between raised radon levels and increased incidences of lung cancer include Darby et al. (1998) in the UK and Field et al. (2000) in the USA. Cliff and Gillmore (2001) pointed out that ecological epidemiological studies should be treated with caution.

In their 2001 paper, Field and Becker (2001) outline their opposing views on residential radon and lung cancer risk. Field (in Field and Becker, 2001) states that ecological epidemiological studies (e.g. Cohen, 1989) are faster and cheaper than prospective cohort and case-control studies but also suggested that they have the least a priori validity for risk assessment. Field (in Field and Becker, 2001) pointed out that since 1981 over 20 ecological radon studies have been published and further suggests that most of these studies have attempted to correlate geographically-based lung cancer rates with summary radon concentrations from the geographical area being studied. Field (in Field and Becker, 2001) qualifies this by observing that an ecological study relies on summary measures, has significant limitations and cannot assess the current or retrospective radon exposure of an individual.

A case-control study by Bochicchio et al. (2005) in which detailed information was gathered on smoking, diet and other risk factors, together with residential history over a 30 year period, suggested that there was an association between residential radon and lung cancer. Darby et al. (2005) examined 13 European case-control studies to determine the risk of lung cancer associated with exposure to radon gas disintegration products in the home. This was collaborative analysis of individual data from nine European countries that concluded that the data provided direct evidence of a statistically significant association of residential radon exposure and lung cancer, accounting for $9 \%$ of deaths from the latter in Europe. Furthermore, Darby et al. (2005) observed that the lung cancer risk has a linear no-threshold (LNT) response to radon concentration, at least down to concentrations of $150 \mathrm{~Bq} \mathrm{~m}^{-3}$. Similarly, work by Krewski et al. (2006) in North America has provided direct evidence of an association between radon in the home and the risk of lung cancer.

\subsection{Radon as a cause of other cancers/illnesses}

Hogan (2003) pointed out that an expert committee was set up in 2001, the Committee Examining Radiation Risks of Internal Emitters (CERRIE), by the UK government to investigate whether radioactive particles that enter the body are more injurious to health than current models predict. This committee reported in October 2004. Some members of this committee believed that 
current models seriously underestimate internal radiation risks while others are of the view that the current ICRP based model overestimates risks (Hogan, 2003). It may be that doses for internal radioactive sources are not correctly calculated and such sources may give localised internal doses many times greater than the ICRP model might indicate. Hogan (2003) highlights that some radionuclides may be more damaging than others. For example radionuclides of strontium may be able to bind to chromosomes and so increase the likelihood of DNA damage.

Muir (2001) suggested that radon and its progeny might cause more genetic damage than anyone has previously realised. Current risk estimates are calculated from explosions in 1945 of atomic bombs in Hiroshima and Nagasaki where radiation levels were very high. Zhou et al. (2001) indicated that the effects of radiation in cells is complicated by the 'bystander effect' in which a radiated cell can change protein production in neighbouring cells (see also Azzam et al., 2001; Zhou et al., 2002, 2005). Straume et al. (2003) highlighted that the final report of the 1986 reassessment of the atomic bomb radiation dosimetry for Hiroshima and Nagasaki, that calculated doses for survivors, recognised that the calculations could be wrong (Roesch, 1986). Little (2003) however, has suggested that the data from the atomic bomb survivors are probably a valuable indicator of the risks of longer-term exposure to ionizing radiation. This is based on work by Straume at al. (2003) on trace amounts of a long-lived radioisotope of nickel produced from copper atoms by high-energy neutrons.

Whilst the main focus of research on radon and health has been the incidence of lung cancer (see Tomášek et al., 2001), there have been several studies that have also suggested possible links to other cancers (Harley and Robbins, 1992; Henshaw et al., 1990; Kendall, 2000; Tomášek et al. 1993). Eatough et al. (1999) and Kendall (2000) highlight that under certain conditions radon decay products can deposit on the skin in sufficient quantities to give a significant dose. The target cells for skin cancer induction lie in the basal layer of the epidermis at a depth between 20 and 100 micrometres (ICRP, 1991). Radon-associated dose to the basal layer of the skin is comparable to the dose to the lung (Harley and Robbins, 1992). However, few measurements of radon progeny deposition onto skin have been published (Eatough et al., 1999). Denman et al. (2003), in a study of abandoned mines in the Southwest of England, suggested that radon progeny can plate out on to skin and hair. The proportion of the nuclides that attach to skin or hair is difficult to assess but it may be significant in terms of understanding dose. Denman et al. (2003) decided to assume in their calculations that all nuclides attach to the skin and none to hairs and point out that therefore their results could point to upper limits for dose estimation. 
Denman et al. (2003) also suggested that the ICRP (1991) study on skin damage was calculated from X-rays, a low Linear Energy Transfer (LET) radiation. The alpha particles given off by radon and its progeny are high LET radiation. Such radiation is more effective in creating biological damage. They observed that visitors to one disused mine in their study reported transient erythema after spending 20 minutes underground with a radon concentration of $600 \mathrm{kBq} \mathrm{m}^{-3}$. Skin dose would have been around $200 \mathrm{mSv}$ and below the thresholds for acute effects. This occurred when there was a high humidity in the mine, with water flowing through it and mist in the air. It is possible that there was therefore a high attached fraction of radon bearing particles in the water vapour. Perhaps either the mist or walkers disturbing the water transiently increased progeny plating out to the skin. The presence of water droplets in the mist may have affected the deposition rate onto the skin surface (Denman et al., 2003). It is important to recognise that skin damage caused by alpha radiation may be a cause for concern. There are some 40,000 new skin cancer cases per year in the UK alone.

Red bone marrow can also receive a significant dose as a result of breathing in radon and its decay products (Kendall, 2000). There has been a concern expressed by a number of authors of a possible to link between raised radon levels and childhood cancers. Dickinson and Parker (2002) investigated whether there was an excess of risk of leukaemia/non-Hodgkin's lymphoma among children of male radiation workers at Sellafield nuclear installation in Cumbria, Northwest England. They suggest that children of radiation workers had a higher risk of Leukaemia/non-Hodgkin's lymphoma than other children. They highlight the possibility that paternal preconceptual irradiation may well be a risk factor that should be considered where leukaemia is concerned. Hogan (2003) indicated that an unusually high number of children have leukaemia in the area, more than current cancer risk models predict. Cartwright et al. (2002) reported on the results of a UK Childhood cancer study related to radon risks and found no evidence to support a link between higher radon concentrations and increased risk of childhood cancers. They went so far as to suggest a possible decreasing risk of cancer with raised radon levels. However, there have been a number of criticisms of this study. One is that the control and case homes were of a different type and therefore they were not comparing like with like. Another criticism is that they employed a statistical deprivation factor to take into account different sociological backgrounds. According to Fryer (2002), if this statistical adjustment is ignored then one can see a positive link between raised radon levels and childhood cancers. The research work by Cartwright et al. (2002) does not match with a number of earlier studies on this topic (e.g. Lucie, 1989; Henshaw et al., 1990; Simmonds et al., 1995). One must also take into account the fact that it takes approximately 15 years to induce lung cancer which is by far and away the major risk associated with raised radon concentrations. The HPA (2009) 
concluded though that there was no clear epidemiological evidence for any association between raised radon concentrations and other cancers.

\subsection{Risk and perceived risk}

Communicating radon risk to the public and to other stakeholders can prove to be a relatively unproductive task. McLaughlin (2003) argued that the European Commission has put much effort into research and research support, but not into getting the message across to the public about risks from radon. McLaughlin (2003), also argued that radiation scientists and regulators need to better communicate risks to the public via the media, using marketing campaigns designed by psychologists and sociologists. The EPA undertook surveys of the American Public's awareness of radon issues in 1993, 1994, 1996 and 1999. The data were gathered by means of telephone interviews of randomly selected adults. The EPA's surveys suggested that in 1993, 67\% of respondents were aware of radon. This figure rose to $73 \%$ in 1994 but fell to $63 \%$ in 1999. Interestingly, 70\% of those surveyed in 1993 suggested that radon was a health hazard - this rose to $88 \%$ in the 1999 survey. Some $59 \%$ of those questioned knew what radon was in 1993, this figure rose to $64 \%$ in the 1999 survey. The EPA suggests that the drop in 1999 to $63 \%$ of those responding being aware of radon was due to a lack of media coverage on radon issues. By way of contrast, a survey undertaken in France in November 2001 suggested that $76 \%$ of the public did not know that high radon concentrations carried a risk, and $65 \%$ of the respondents were unconcerned about the risks. $52 \%$ of those surveyed felt that they would like to know the radon level, but $43 \%$ said that they were not interested (McLaughlin, 2003). When it came to being prepared to spend money to remediate a property, $20 \%$ said that they would be willing to spend less than $€ 750$ (the price of remediating the average UK home; about $£ 500$ ), but only $5 \%$ would be willing to spend $€ 1,500-3,000$ (McLaughlin, 2003). Some of the reasons suggested by McLaughlin (2003) for this lack of concern were; an inability to sense radon; there were no immediate health effects; exposure to radon was regarded as natural; there was no-one to blame and therefore no perceived enemy; indeed 'where are the bodies'?; and lastly inertia by official bodies. McLaughlin (2003) argues that we need to be quantitative about radon lung cancer risks. The radon reference level of $200 \mathrm{~Bq} \mathrm{~m}^{-3}$ would give an exposure of 3-5 mSv per year which is an excess lifetime risk of lung cancer of 1$2 \%$.

Risk is often defined as the probability that an untoward event will happen multiplied by the impact it could have if it did happen. An acute risk might be the risk of a hurricane destroying a town calculated by multiplying the probability of it occurring by the amount of damage it could 
cause. Many risks (particularly environmental pollution) that we face however are chronic ones, where the consequences build up slowly (Gilbert et al., 2002). Some authors have gone so far as to rank risks in a risk ladder. In an article in The Times $\left(9^{\text {th }}\right.$ December 1994, p.14) it was suggested that scientists have not measured the risks of normal life adequately in the past. One example given concerned radon gas. The question posed was 'was living in Cornwall with its raised radon levels more risky than eating British beef?'.

Denman (2002) undertook a study of 20 different activities which have some risk of death and asked three different groups of people (school children, university students and health care professionals) to rank those risks. Their rankings were then compared with expert rankings. Denman found that nearly all risks from X-rays were underestimated, while the risk from CT scanning was significantly underestimated. In contrast to this most people overestimated the risks from driving but, particularly worryingly, school children underestimated the risks associated with smoking. Everyone underestimated the risk associated with climbing Everest, the average placing being 10 out of 20, the lowest number being the highest risk. There have been, between 1921 and 1998, 1,052 individual ascents with 160 deaths above base camp. The risks associated with radon were placed at 5 by the expert rankings, but the majority in the survey placed this risk in the lower half of the rankings.

The public perception of a particular risk then can be very different from the expert view. As pointed out by Gilbert et al. (2002) even when two events appear at a similar point on a risk ladder, public perception of the significance of those risks may be quite different (and even dangerously inappropriate). Another key issue when considering the comparability of risk is whether or not there has been a reliable assessment of all the factors that influence a particular risk? Where radon is concerned there is still much work to be done to understand influences/controls on concentrations, as highlighted by a study by Phillips et al. (2003) for DEFRA in the UK.

\section{Radon in the Built Environment: radon as an indoor air pollutant}

\subsection{Exposure and Dose, Units and Equilibrium Factors}

The unit of radioactivity commonly used to convey concentrations of radon is the Becquerel (one disintegration per second) per cubic metre of air (i.e. $\mathrm{Bq} \mathrm{m}^{-3}$ ). Since the short-lived decay products of radon (i.e. progeny or daughters) are also radioactive, then the concentration of these products may also be specified in $\mathrm{Bq} \mathrm{m}^{-3}$. The total energy carried by all the alpha particles that 
will be produced by the complete decay of all the short-lived progeny in a unit volume of air is referred to as potential alpha energy concentration (PAEC) and is expressed as $\mathrm{J} \mathrm{m}^{-3}$. The airborne dose in a room depends then primarily on the PAEC of the radon progeny and their activity size distribution (Steck et al., 2008). Radioactivity may be expressed as the product of concentration and time, in other words $\mathrm{Bq} \mathrm{h} \mathrm{m}$. For progeny, the unit of cumulative exposure would be $\mathrm{J} \mathrm{h} \mathrm{m}^{-3}$. The PAEC level can be associated with a value of radon concentration if the extent to which the radon progeny are in equilibrium with the radon are known. If the activity of a decay product is $50 \%$ of the parent then the equilibrium factor $(\mathrm{F})$ of the decay product is 0.5 . To calculate the risk factors from radon in US houses, F is often taken as 0.4 according to Steck et al. (2008). However as Steck et al. (2008) also highlight F can vary considerably as a result of aerosol particle concentration surface deposition and ventilation which will affect the progeny activity size distribution.

Thus, the equilibrium factor is a key measure in determining dose to a person: for most domestic properties an equilibrium factor of 0.4 to 0.6 is often assumed. UNSCEAR (1988) suggested that for domestic environments the equilibrium factor is typically 0.35 . In most of their dose calculations Gillmore et al. $(2001,2002)$ used an equilibrium factor of 0.5. In initial surveys in some mines in the south west of England, the equilibrium factor varied from 0.17 to 0.4 (Gillmore et al. 2001).

Another unit often used, mostly in the USA is pCi $\mathrm{L}^{-1}\left(1 \mathrm{pCi} \mathrm{L}{ }^{-1}=37 \mathrm{~Bq} \mathrm{~m}^{-3}\right)$. Working Levels - based on a concept of what is acceptable; (see Waltham, 1991; Gillmore et al., 2001) - are also used to estimate dose: 1 Working Level (WL) equalling $2.0810^{-5} \mathrm{~J} \mathrm{~m}^{-3}\left(130 \mathrm{GeV} \mathrm{L}^{-1}\right)$ alpha-particle energy density. For $\mathrm{F}=0.5$, Lao (1990) suggested that $1 \mathrm{WL}=7.4 \mathrm{kBq} \mathrm{m}^{-3}\left(200 \mathrm{pCi} \mathrm{L}^{-1}\right)$.

\subsection{Radon Measurement in the Built Environment.}

There are five commonly used techniques for measuring radon concentration in the home (Cliff and Gillmore, 2001, Phillips et al., 2003; Groves-Kirkby et al., 2005); alpha-track etch detectors, scintillation detectors, electrets, activated charcoal canisters and thermoluminescence based detectors. Alpha-track etch detectors are perhaps the most commonly used due to their low cost, compactness and simplicity of use. These detectors provide a reasonably accurate assessment of long-term exposure, and are normally deployed for shorter than 90 days (Phillips et al., 2003). When placed in the home they are passive and unobtrusive. Alpha-track detectors consist of plastic (e.g. CR39, LR115) films and record radon decay products in terms of the damage ('tracks') that emitted alpha-particles cause. Exposed detectors are processed in a laboratory where these tracks 
are exposed by etching using, for example, a hot caustic soda solution, and can then be imaged and counted using 2D or 3D microscopy (see Wertheim et al., 2009, 2010). Having said this, given the correct set of circumstances (and container/chip design) they can be (and are being) used increasingly for shorter period testing of a few weeks, although shorter-period measurements are more variable due to the variable response of radon emissions to, for example, weather conditions which shorter measurement periods average-out to lesser extents than longer ones. Electret detectors may also be prone to inaccuracies due to variation in relative humidity of the atmosphere (Phillips et al., 2003; Groves-Kirkby et al., 2005). Active measurements using continuous sampling or grab sampling can provide accurate results but such devices can be expensive, relatively bulky and noisy. They are sometimes used for short-term testing over hours or a few days, but this is not appropriate for estimating yearly exposure given radon's variable nature. Passive measurements using activated charcoal can produce very accurate short-term results over periods up to $c a$. 7 days (Phillips et al., 2003).

\subsection{Action Levels.}

The International Commission on Radiological Protection (ICRP) have produced guidelines to indicate at what concentrations remediation procedures should be put into place (ICRP, 1987). Most European countries follow these to a greater or lesser extent. Table 4 illustrates how policies in the EU have developed over recent years and the organisations concerned. In the UK and Ireland (see Table 3 for policy development outlines) the threshold concentrations above which remediation should take place are $200 \mathrm{~Bq} \mathrm{~m}^{-3}$ and $400 \mathrm{~Bq} \mathrm{~m}^{-3}$ in the home and workplace respectively (i.e. the domestic and workplace Action Levels). However, in 2010 a new domestic Target Level of $100 \mathrm{~Bq}$ $\mathrm{m}^{-3}$ was introduced (in addition to retaining the existing Action Level) following publication of WHO guidelines (2009) which recommended a reduction of indoor radon concentrations (HPA, 2010). In the USA the limit is set at $4 \mathrm{pCi} \mathrm{L}^{-1}\left(148 \mathrm{~Bq} \mathrm{~m}^{-3}\right)$. Table 2 highlights developments in US policy/legislation since 1969. In 1988, the Indoor Radon Abatement Act (IRAA) directed the EPA to list and identify areas of the USA with the potential for elevated radon concentrations.

There are quite a number of European countries that do not follow the ICRP (2009) guidelines or WHO (2009) recommendations. Table 5 outlines radon policies in seven European countries plus several non-EU ones. For example, Germany (Table 6) has a significant radon problem but legislation appears to be focused on workers underground and 'work activities' (particularly in waterworks, where radon can emerge due to degassing from water) and consequently there appears to be a lack of interest in the issue by the Public. In Switzerland (Table 7) in order for a Canton to 
be classified as a Radon Area there used to have to be only one or two houses above $1 \mathrm{kBq} \mathrm{m}^{-3}$. This meant that it was possible to have a Canton where only a few houses had very raised radon concentrations but the majority were relatively low. That area was then officially regarded as one with a radon problem. Conversely an area could have had many homes above $200 \mathrm{~Bq} \mathrm{~m}^{-3}$ but none in the $1 \mathrm{kBq} \mathrm{m}^{-3}$ or above range, in which case it would officially have been regarded as an area without a radon problem even if the risk to the majority of the population was greater than in an official Radon Area. The Swiss government has therefore changed the approach to one where the classification is based on percentage of homes with over $200 \mathrm{~Bq} \mathrm{~m}^{-3}$.

\subsection{Annual Averages, Seasonal and Other Variations}

Radon concentration in the built environment will vary throughout the year, with the greatest concentrations often being during the winter months. Outdoor concentrations meanwhile are at their greatest during the summer months (Pinel et al., 1995). The latter authors argue that as indoor radon variations are subject to seasonal variation, and may be impractical to measure over a year, it is necessary to develop some form of seasonal correction. PHE therefore make allowance for this variation by applying an estimated seasonal correction factor to actual radon measurements, in order to derive a mean annual exposure level in a house or workplace. The correction factor that the HPA apply is of course based on measurements taken for UK homes across a range of geological formations. For Finnish homes, typical correction factors vary in the range of 1.0-0.7, depending on the outdoor temperature and on radon concentration (Arvela, 1995).

A study was undertaken in the UK because a concern had been expressed that seasonal correction factors derived from the work of Wrixon et al. (1988) and others might not be appropriate in areas where the radon levels were high, such as in the Southwest of England (Pinel et $a l ., 1995)$. The underlying geology of this region is generally speaking very different to many parts of the UK, as much is underlain by large granite bodies. Grainger et al. (2000) suggested that as the UK seasonal correction factors had been derived from the mainland UK database, which is dependent on UK geology, seasonal correction factors may need to be different for the Isle of Man which has a very different geology. They measured radon levels following PHE protocols in homes of over 400 families for a period of 3 months in the winter. They also measured seasonal variation for 12 months in 10 homes and from this a seasonal correction factor was derived by dividing the arithmetic mean for each time period by the annual arithmetic mean. This was then compared with PHE correction factors. This study confirmed previous patterns observed in the UK of lower radon concentrations in the summer months due to ventilation effects. Using the Mann-Whitney test, it 
was suggested that the difference between the Isle of Man and UK median radon values was not significant. They did derive different seasonal correction factors, but suggested that despite this the difference was not statistically significant. They concluded that PHE seasonal correction factors for the UK mainland may therefore be applied to the Isle of Man, despite the different underlying geology. Grainger et al. (2000) also suggested that there was no clear link between geological regions and different factors. However, high levels on the Isle of Man were noted in the southern half of the Island and included the highland regions and the ex-mining areas.

There are a number of issues that need to be remembered when considering possible links between geology and seasonal correction. The Grainger et al. (2000) study only used 10 homes as the source for its seasonal data. Two of the ten homes could not be used to determine seasonal correction as the detectors had not been used according to PHE protocols (as the authors observed). Like many such studies, Grainger et al. (2000) also do not take into account the enormous variability that any one geological formation will have in uranium/radium content. Calculation of seasonal correction factors also depends on the assumption that outdoor air has a mean radon level of $4 \mathrm{~Bq} \mathrm{~m}^{-3}$ with no significant seasonal variation (Wrixon et al. 1988). This may be the case on the large-scale but there are significant local variations. Outdoor radon levels have been measured at one UK site over a year and generally found higher radon concentrations in the autumn than in the spring (Gale and Peaple, 1958). It is unclear if this applies elsewhere in the UK (Pinel at al., 1995). It is also important to recognise that different geological conditions can give rise to trends in indoor radon levels that do not fit the seasonal pattern of variation suggested by many authors. Arvela $e t$ al. $(1988 ; 1994)$ and Arvela (1995) have clearly shown that patterns of air movement in glacial sediments (in this case sandy eskers) can create very different summer/winter radon levels in homes in Finland. This may be because of the very porous nature of such sediments allowing air convection in the ground (Pinel et al., 1995). Similar variations occur in homes on karstic limestones (Wilson et al., 1991). There is a significant area of the UK where limestone either outcrops or subcrops. Homes in Derbyshire may have a different seasonal trend to that observed in other parts of the UK (Pinel et al., 1995).

The same correction factors should not necessarily be applied everywhere in the UK (Pinel et al., 1995 ; Gillmore et al., 2005a; Crockett et al. 2016, this volume). Caution should be used in applying seasonal correction factors due to the significant geological variability that exists. Gunby et al. (1993), suggested that $78 \%$ of the variation in radon levels in homes in their study remained unexplained. 
Work by Crockett et al. (2006), however, has shown another complication that has particular relevance to weekly and shorter measurement periods in that radon concentrations in the built environment can be subject to tidal-periodic variations. These observed variations are cyclic at the 14-15 day (lunar bi-weekly) tidal period and lag new/full moons by varying periods of days and are dependent on factors such as underlying geology and soil/rock hydration. Crockett et al. (2006) concluded that, with respect to any Action Level (in the UK currently $200 \mathrm{~Bq} \mathrm{~m}^{-3}$ for domestic and $400 \mathrm{~Bq} \mathrm{~m}^{-3}$ workplace), 1-week measurements could erroneously indicate either that a building is safe when levels are unsafe, or vice-versa, if measured around a tidal-cycle radon maximum or minimum respectively. They have therefore suggested that short-term testing should be for 14-15 day periods, i.e. one bi-weekly tidal cycle, as a minimum and that any longer measurement period should ideally be for an integral multiple period of this - noting that 'conventional' 1 month and 3 month periods are effectively integral multiples of this tidal period.

\subsection{Radon in homes and workplaces.}

By far and away the most significant impact of raised radon concentrations on human health is exposure in the home, and this is reflected in the various national policies that have been adopted (see Tables 2-7). Over the last decade or so, governments in many countries have made efforts to persuade homeowners to reduce radon concentrations. In the USA, radon testing has become a part of the buying/selling process. In Sweden, testing is compulsory. The UK, like many countries, has relied on voluntary actions to reduce home radon concentrations (Rothstein, 2003a). As stated previously, the average ${ }^{222} \mathrm{Rn}$ level inside UK homes is $20 \mathrm{~Bq} \mathrm{~m}^{-3}$. However, there are areas in the UK where average levels are considerably higher than this.

There are many factors that influence radon in the home. Gunby et al. (1993) suggested that one of the most significant factors affecting indoor radon concentrations in the UK is the rock type on which a home (or other building) is built (see Table 7). Other factors include the building style or type of home which includes floor type and levels, building materials (see Table 8), draught proofing and whether the home is double-glazed. In a typical UK building of masonry where radon occurs at the UK national average $\left(20 \mathrm{~Bq} \mathrm{~m}^{-3}\right) 60 \%$ of the radon comes from the underlying soil/rock, $25 \%$ from building material itself, $12 \%$ from fresh air, $2 \%$ from the water supply and $1 \%$ from domestic gas (Appleton et al., in press). Marley (2001) suggested that radon variability in the built environment is a result (at least in part) of the variability of atmospheric surface boundary layer conditions and suggested that seasonal variation of radon in homes is due to changes in water vapour pressure. 
Rothstein (2003a,b) pointed out that radon in the workplace, despite legislation (see Table 4 for EU policies based on Euratom, plus Table 3), is not regarded by many employers as a health and safety issue. EU policies (Table 4) include a recommended Action Level of 500-1,000 $\mathrm{Bq} \mathrm{m}^{-3}$ for work places, while Italy has a limit of $500 \mathrm{~Bq} \mathrm{~m}^{-3}$ and Greece $200 \mathrm{~Bq} \mathrm{~m}^{-3}$ for new work places (see Table 5). Dixon (2003) suggested that the level of awareness about radon at work is very variable in the UK, with smaller companies generally being less well informed, despite the legal responsibilities of all employers in the UK. According to the IRR (1999), made under the Health and Safety at Work Act of 1974, the radon level in the workplace above which remediation should take place (the Action Level) is $400 \mathrm{~Bq} \mathrm{~m}^{-3}$ averaged over any 24 hour period. This is except where the concentration of the short-lived radon daughters in air (averaged over an 8 hour interval) does not exceed $6.24 \times 10-7 \mathrm{~J} \mathrm{~m}^{-3}$ (PAEC).

Radon gas concentrations in the built environment, i.e. workplace, home and other buildings, will vary according to underlying geology (Gillmore et al., 2005a), type of premises and work activity. Employers whose premises are in RAAs should test for radon as part of their compliance with Health and Safety Risk Assessments required by the Management of Health and Safety at Work Regulations (1999). It is interesting to note that the Health and Safety Executive (HSE; the relevant Government Agency in the UK) recognise that measurements over short periods e.g. 8 or 24 hour periods may not be representative of true annual average radon concentrations and therefore generally recommends measurements over several months. Once the measurements have been made, the employer has a duty to manage radon exposures under IRR (1999) to ensure that thresholds are not exceeded. If those thresholds are exceeded the employer must comply with the regulations and take remedial action to reduce radon gas concentrations to below the IRR (1999) thresholds. With such clear legal guidance it is perhaps surprising that the majority of employers often do not comply. In the UK, PHE suggest that radon in the workplace may be responsible for as many as 250 lung cancers per year. To put this into perspective this is the same number as are killed by work-related accidents (Rothstein, 2003a,b). Since 1985, when Regulations were introduced to control radon in the workplace only $10 \%$ of potentially-affected properties in England and Wales have been tested. Rothstein (2003a) point out that it would take over 20 years to protect the suggested 150,000 workplaces affected. Rothstein (2003a,b) suggests that part of the problem is the unfamiliarity of Health and Safety inspectors with the radon issue. 


\subsection{Radon mitigation and remediation: cost-benefit analysis and cost- effectiveness.}

Indoor radon concentrations can be reduced using a range of mitigation techniques (Table 9 for mitigation techniques). It is interesting to note that by 2003 the number of dwellings that have been remediated in the USA was 320,000, and 30,000 in Sweden, but in the UK only ca. 8,000-10,000 homes had been remediated. The corresponding figure for Ireland was even lower, at less than 50 (McLaughlin, 2003). According to the European Commission (90/143/Euratom), preventative measures should be installed for future buildings according to a design level established by regulations/standards. Most of the activity in the UK, and particularly in Ireland, is focused on preventative measures in new dwellings rather than reducing concentrations in the existing housing stock. Radon testing can be low cost and remediation of a property is often straightforward and relatively inexpensive, about $£ 500$ (2003 value) per average UK house by professionals. Yet as Rothstein (2003a) has pointed out, the rates of testing and remediation in the UK have been less than expected. Bradley et al. (1997) suggested that in Devon and Cornwall only $10 \%$ of those householders with raised radon concentrations had remediated. Ryan and Kelleher (1999) suggested that even when householders knew of the presence of high radon concentrations in their home they rarely remediated. Phillips et al. (2000) pointed out that the majority of the public consider the health risks from radon to be negligible.

The use of cost-benefit analysis in reaching risk decisions raises quite a number of ethical and philosophical issues (Gilbert et al., 2002). For example, can a human life be reduced to a cash value? In some circumstances, the answer is yes: when in the USA in 1972 a car manufacturer calculated how much it would cost them to solve an alleged problem with a new motor car - the petrol tank allegedly was vulnerable in a rear collision and allegedly could explode on impact - they calculated the value of a life to be $\$ 200,000$. This figure was made up of future productivity losses, the victims pain and suffering, insurance costs, property damage, legal and court aid and medical costs.

A form of cost benefit analysis has been used when assessing the effectiveness of radon remediation in several counties in England (Coskeran et al., 2002). They suggested that in three regions examined in their study (Northamptonshire 2, 3 and North Oxfordshire), radon remediation programmes were cost-effective, whereas those in two areas (Northamptonshire 1 and North Somerset) were not. This approach relies on comparing interventions with a common outcome (such as lung cancers saved) in order to assess the effectiveness of a certain amount of resources in 
a selected population. It was calculated that if only $10 \%$ of those homes that were above the Action Level were remediated, the annual cost per lung cancer saved in the five study areas would be in the order of $£ 184,212$ in North Oxfordshire to $£ 819,514$ in North Somerset. On the basis of this work they suggested that cost per life year gained varied from $£ 11,352$ in Northamptonshire to $£ 57,085$ in North Somerset. Clearly North Somerset is the highest cost area with the cost per life year gained over five times that of the lowest area. The effect of increased remediation rates does change the outcome considerably, with the cost per life year gained dropping significantly. Garber and Phelps (1997) suggested that health programmes should be considered cost-effective for policy purposes if the cost per life year gained is less than double the average income. Coskeran et al. (2002) have made the difficult decision that in two areas, the health authorities would have found it 'better' to use limited resources elsewhere to improve the health of local inhabitants as a result of poor remediation rates.

In the USA the EPA estimates an average cost per life saved of $\$ 80,000$ for radon-resistant new construction, and $\$ 400,000$ for mitigating existing homes (see EPA 2012). In a study comparing radon mitigation programmes in Northamptonshire, UK, Denman (2002) suggested that the cost per cancer averted annually from a NRPB promotion to reduce exposure to radiation from dental x-rays was over $£ 16 \mathrm{M}$. The cost per cancer averted annually for radon reduction in new build domestic properties was by comparison around $£ 4$ M. If all existing domestic properties that were tested and found to be high remediated, the cost per cancer averted annually would be in the order of $£ 1 \mathrm{M}$. However, as only a small percentage of those home owners actually remediated after testing this cost may rise to over $£ 14 \mathrm{M}$. By comparison mitigating schools gave rise to a total cost per cancer averted annually of less than $£ 1 \mathrm{M}$.

\section{Future research and policy development.}

One reason why radon control in the built (and natural) environment in the UK has not been entirely successful is that it is not identified as an important national objective (Rothstein, 2003a), suggesting that the UK government in the early 1990s effectively discouraged vigorous enforcement of radon controls. Without victim groups (or special interest groups) scientists are struggling to persuade policy makers to prioritise radon controls. Rothstein (2003b) indicated that there are striking similarities between the radon issue and the way in which BSE controls were not enforced at UK slaughterhouses, and how the government's initial approach to the issue hampered its solution. Irwin (2003) suggested that the BSE crisis marked a change in government thinking and that there was a recognition that there is a problem with communicating with members of the 
public on such issues. This may be so, but the UK government has not identified the radon issue as one in which greater public awareness and debate is required. This is compounded by the fact that public confidence in science has been undermined by the BSE crisis. Unlike other environmental issues such as GM crops, there are also few Non-Governmental Organisations pushing the radon agenda forward. However, both the Radon Council and the CIEH (Chartered Institute of Environmental Health) have been campaigning since the late 1980s - early 1990s to persuade the Government to change their radon initiatives to make a more meaningful impact on public uptake of radon protection where radon health risks are concerned (see Blythe, 2001). Recently in 2013, other groups have taken an interest in radon issues, such as the lobby group the Environmental Industries Commission. This is being driven by contaminated land concerns and associated ground gas pollution measures.

Watts (2005) highlighted that there appears to be a disinclination amongst householders to do anything about raised radon concentrations. Of householders whose homes are above the Action Level of $200 \mathrm{~Bq} \mathrm{~m}^{-3}$ in the UK, only about $10 \%$ were addressing the issue. The Parliamentary Office of Science and Technology suggests that there are four reasons for this; a reluctance to remediate if the radon concentration is only slightly above the Action Level; a tolerance of natural as opposed to man-produced radiation; poor access to good advice; inertia.

In order to address the issue of poor uptake of radon remediation, the UK government developed a 'radon roll-out programme'. This is a targeted governmental response aimed at educating mainly Local Authorities, but also agents such as estate agents etc., with a view to increasing uptake of radon remediation. However, the programmes effectiveness in getting the message across to the public has been called into question (Papworth, 2005).

In the USA, short-term radon tests are often undertaken at the time of sale. This approach has gone a long way towards addressing the radon issue in homes in the USA (Ahern, 2005; Angell, 2012). Therefore, perhaps short-term testing at the point of sale should be adopted in the UK in order to promote radon awareness and improve remediation rates. However, research by Crockett et al. $(2005 ; 2006)$ and Groves-Kirkby et al. (2006) in the UK has suggested that tidal effects on radon concentrations in the home would be difficult to accommodate with anything less than a 2week short-term testing due to cyclic tidal loading.

Where radon in the workplace is concerned, the uptake of remediation is low in the UK despite regulatory and legislative control. In Ireland, the RPII has resorted to taking legal action through 
the courts because of employers alleged non-compliance with the relevant legislation. Rothstein (2003a) suggests that HSE and Environmental Health Officers are not really pushing this issue forward and so there is little dose reduction to the general public in the UK.

An alternative approach to the radon problem is that Health Policy makers and Primary Health Care Trusts in the UK could consider developing strategies to work with the population in areas where radon has been identified as a problem. However, such activity must be cost-effective as pointed out by Coskeran et al. (2002). 


\section{References}

Ahern, B., Personal Communication. 2005.

Åkerblom, G., Radon legislation and national guidelines. ERRICCA, European Research into Radon in Construction Concerted Action, the Swedish Radiation Protection Institute SSI Report no. $99,1999$.

Al-Doorie, F. N., Heaton, B. and Martin, C. J., A study of ${ }^{222} \mathrm{Rn}$ in well water suplies in the area of Aberdeen. Journal of Environmental Radioactivity 18, 163-173, 1993.

Argonne National Laboratory, Human Health Factsheet, May 2005.

Angell, W., Personal Communication. 2012.

Appleton, J. D., Jones, D. G., Miles, J. C. H. and Scivyer, C., Radon Gas Hazard. In: Giles, D. P., Griffiths, J. S., (eds.), Geological Hazards in the UK: their Occurrence, Monitoring and Mitigation. Geological Society, London, Engineering Geology Special Publication, UK (in press).

Arvela, H., Voutilainen, A., Mäkeläinen, I., Castren, O. and Winqvist, K., Comparison of predicated and measured variations of indoor radon concentration. Radiation Protection Dosimetry, 24(1-4), 231-235, 1988.

Arvela H., Voutilainen, A., Honkamaa, T. and Rosenberg, A., High indoor radon variations and the thermal behavior of Eskers. Health Physics, 67(3), 254-260, 1994.

Arvela, H., Seasonal variation in radon concentration of 3000 dwellings with model comparisons. Radiation Protection Dosimetry, 59(1), 33-42, 1995.

Azzam, E. I., de Toledo, S. M. and Little, J. B., Direct evidence for the participation of gap junction mediated intercellular communication in the transmission of damage signals from $\alpha$-particle irradiated to nonirradiated cells. Proceedings of the National Academy of Sciences, 98(2), $473-$ 478, 2001

BEIR (Biological Effects of Ionizing Radiation) VI. 1999. Committee on the Health Risks of Exposure to Radon, Board on Radiation Effects Research, U.S. National Research Council. National Academy Press, Washington, DC.

Becker, K., Health Effects of High Radon Environments in Central Europe: Another Test for the LNT Hypothesis? Nonlinearity in Biology, 1(1) 3-35. 2003. 
Blythe, A., A critical analysis of the UK local government response to radon. Environmental Management and Health, 12(5), 492-499, 2001.

Bochicchio, F., Forastiere, F., Farchi, S., Quarto, M., Axelson, A., Residential radon exposure, diet and lung cancer: a case-control study in the Mediterranean region. International Journal of Cancer, 114, 983-991, 2005.

British Geological Survey (BGS), Geohazard Note, Naturally Occurring Radon, May 2012, 4pp.

Bruenger F.W., Lloyd, R.D., Miller, S.C., Taylor, G.N., Angus, W., Huth, D.A., Occurrence of mammary tumors in beagles given radium-226. Radiation Research, 138, 423-434, 1994.

Building Research Establishment Report BR211 - Radon: Guidance on protective measures for new dwellings, Garston, Watford, UK: BRE, 1999.

Cartwright, R. A., Law, G., Roman, E., Gurney, K. A., Gilman, E., Eden, O. B., Mott, M., Muir, K., Goodhead, D. and Kendall, G., The United Kingdom Childhood Cancer Study of exposure to domestic sources of ionising radiation: 1: radon gas. British Journal of Cancer, 86, 1721-1726, 2002.

Cohen, B., Expected indoor Rn-222 levels in counties with very high and very low lung cancer rates, Health Physics, 57, 897-907, 1989.

Colgan, P. A. and Gutierrez, J. National approaches to controlling exposure to radon. $6^{\text {th }}$ Symposium on the Natural Radiation Environment, Montreal, 1995.

Coskeran T., Denman, A. R., Phillips, P. S. and Gillmore, G. K., A critical comparison of the costeffectiveness of domestic radon remediation programmes in three Counties of England. Journal of Environmental Radioactivity, 62(2), 129-144, 2002.

Cliff, K. and Gillmore, G. K. (eds. ), The Radon Manual. Shepperton, UK: The Radon Council of Great Britain, 2001.

Crockett, R. G. M., Gillmore, G. K., Phillips, P. S., Denman, A. R. and Groves-Kirkby, C. J., Radon Anomalies Preceding Earthquakes which occurred in the UK, in Summer and Autumn 2002. Science of the Total Environment, 364(1-3), 138-148, 2006.

Crockett, R. G. M., Gillmore, G. K., Phillips, P. S., Denman, A. R. and Groves-Kirkby, C. J., Tidal Synchronicity of Built-Environment Radon Levels in the UK. Geophysical Research Letters. 33, L05308, doi: 10. 1029/2005GL024950, 2006.

Crockett, R. G. M., Groves-Kirkby, C. J., Denman, A. R. and Phillips, P. S., Significant Annual and Sub-Annual Cycles in Indoor Radon Concentrations: Seasonal Variation and Correction. This volume. 2016. 
Darby, S., Whitley, E., Silcocks, P., Thakrar, B., Green, M., Lomas, P., Miles, J., Reeves, G., Fearn, T. and Doll, R., Risk of Lung Cancer associated with residential radon exposure in South-West England: a case-control study, British Journal of Cancer, 78, 394-408, 1998.

Darby, S., Hill, D., Auvinen, A., Barros-Dios, J. M., Baysson, H., Bochicchio, F., Deo, H., Falk, R., Forastiere, F., Hakama, M., Heid, I., Kreienbrock, L., Kreuzer, M., Lagarde, F., Mäkeläinen, I., Muirhead, C., Oberaigner, W., Pershagen, G., Ruano-Ravina, A., Ruosteenoja, E., Schaffrath Rosario, A., Tirmarche, M., Tomášek, L., Whitley, E., Wichmann, H. E. and Doll, R., Radon in homes and risk of lung cancer: collaborative analysis of individual data from 13 European casecontrol studies. British Medical Journal, 330(7485), 223-226, 2005.

Denman, A. R., Personal Communication. 2002.

Denman, A. R., Eatough, J. P., Gillmore, G. K. and Phillips, P. S., Assessment of Health Risks to Skin and Lung of Elevated Radon Levels in Abandoned Mines. Health Physics, 85(6), 733-739, 2003.

Denman, A. R., Groves-Kirkby, C. J., Phillips, P. S., Crockett, R. G. M., Woolridge, A and Gillmore, G. K., The Practical Use of Electrets in a Public Health Radon Remediation Campaign. Journal of Environmental Radioactivity, 84(3), 375-391, 2005.

Dixon, D., An overview of issues in the reduction of UK radon exposure. Environmental Management and Health, 12(5), 516-524, 2001.

Dixon, D., Evacuate the workplace? Environmental Radon Newsletter, 36, 2, 2003.

Dixon, D., Personal Communication. 2006.

Dubois, G., An Overview of Radon Surveys in Europe, European Commission Direcorate-General Joint Research Centre, EUR21892EN, PUBSY1429, Luxembourg, 2005.

Duggan, M. J., Howell, D. M. and Soilleux, P. J., Concentrations of radon-222 on coal mines in England and Scotland. Nature, 219, 1149, 1968.

Eatough, J. P., Worley, A. and Moss, G. R., Personal monitoring of ${ }^{218}$ Po and ${ }^{214}$ Po radionuclide deposition onto individuals under normal environmental exposure conditions. Physics in Medicine and Biology, 44, 2227-2239, 1999.

Eheman, C., Carson, B., Rifenburg, J., and Hoffman, D., Occupational exposure to radon daughters in Mammoth Cave National Park. Health Physics, 60, 831-835, 1991.

Ellard, A., Personal Communication. 2006. 
European Environment and Health Information System (ENHIS). Radon levels in dwellings. Fact Sheet no.4.6, RPG4_RadEx1, World Health Organization, May 2007.

EPA. A Citizen's Guide to Radon: The guide to protecting yourself and your family from Radon. EPA/OAR/IED (6690J), EPA 402-K-12-002, 2012.

Erickson, B. E., The Therapeutic Use of Radon: A Biomedical Treatment in Europe; an "Alternative" Remedy in the United States. Dose-Response, 5:48-62, 2007. DOI: 10.2203/doseresponse.06-007.

Field, R. W., Steck, D. J., Smith, B. J., Brus, C. P., Neuberger, J. S., Fisher, E. F., Platz, C. E., Robinson, R. A., Woolson, R. F. and Lynch, C. F., Residtential radon gas exposure and lung cancer: the Iowa Radon lung cancer study. American Journal of Epidemiology, 151, 1091-1102, 2000 .

Field, R. W. and Becker, K., Does exposure to residential radon increase the risk of lung cancer? Radiation Protection Dosimetry, 95(1), 75-81, 2001.

Fryer, F., Personal Communication. 2002.

Gale, H. J. and Peaple, L. H. J., A study of the radon content of ground-level air at Harwell. International Journal of Air Pollution, 1(102), 103-109, 1958.

Gilbert, N., Clift, R., Davis, K., Edwards, M., Horsley, D., Irwin, A., Kennedy, J., O’Reilly, J., Radford, T., Wynne, B., Yearly, S. and Eades, A., The Societal Aspects of Risk. Royal Academy of Engineering report, 20pp., 2002.

Gillmore, G. K., Sperrin, M., Phillips, P. and Denman, A., Radon Hazards, Geology and Exposure of Cave Users: a case study and some theoretical perspectives. Ecotoxicology and Environmental Safety, 46(3), 279-288, 2000a.

Gillmore, G. K., Sperrin, M., Phillips, P. and Denman, A., Radon-prone Geological Formations and implications for cave users. Technology 7(6), 645-655, $2000 \mathrm{~b}$.

Gillmore, G. K., Phillips, P. Denman, A., Sperrin, M. and Pearce, G., Radon levels in Abandoned Metalliferous Mines, Devon, Southwest England. Ecotoxicology and Environmental Safety 49, 291-292, 2001.

Gillmore, G. K., Phillips, P. S., Denman, A. R. and Gilbertson, D. D., Radon in the Creswell Crags Permian limestone caves. Journal of Environmental Radioactivity 62 (2), 165-179, 2002a.

Gillmore, G. K., Grattan, J., Pyatt, F. B., Phillips, P. S. and Pearce, G., Radon, water and abandoned metalliferous mines in the UK: Environmental and Human Health implications. In: Merkel, B. J., Planer-Freidrich, B. and Woldersdorfer C. (eds. ), Uranium in the Aquatic Environment. 
Proceedings of the International Conference Uranium Mining and Hydrogeology III and the International Mine Water Association Symposium, Freiberg, Germany, 15-21 September 2002, Springer, 65-76, 2002b.

Gillmore, G. K., Phillips, P. S. and Denman, A. R., The effects of geology and the impact of seasonal correction factors on indoor radon levels: a case study approach. Journal of Environmental Radioactivity 84(3), 469-479, 2005a.

Gillmore, G. K., Gilbertson, D., Grattan, J., Hunt, C., McLaren, S., Pyatt, B., mani Banda, R., Barker, G., Denman, A., Phillips, P. and Reynolds, T., The potential risk from radon-222 posed to archaeologists and earth scientists: reconnaissance study of radon concentrations, excavations and archaeological shelters in the Great Cave of Niah, Sarawak, Malaysia. Ecotoxicology and Environmental Safety, 60(2), 213-227, 2005b.

Gillmore, G.K., Crockett, R., Denman, T., Flowers, A., and Harris, R., Radium dial watches, a forgotten legacy? Environment International, 45, 91-98, 2012.

Girault, F., Perrier, F. and Przylibski, T. A., Radon-222 and radium-226 in water: a review. Radon, Health and Natural Hazards... This volume...

Grainger, P., Shalla, S. H., Preece, A. W. and Goodfellow, S. A., Home radon levels and seasonal correction factors for the Isle of Man. Physics in Medicine and Biology, 45, 2247-2252, 2000.

Green, B.M.R., Miles, J.C.H., Rees, D.M., HPA-RPD-051 - Radon in Dwellings in Scotland: 2008 Review and Atlas, 2009.

Groves-Kirkby, C. J., Denman, A. R., Crockett, R. G. M., Phillips, P. S. and Gillmore, G. K. Identification of Tidal and Climatic Influences within Domestic Radon Time-Series from Northamptonshire, UK. Science of the Total Environment, 367(1), 191-202, 2006.

Groves-Kirkby, C. J., Denman, A. R., Crockett, R. G. M., Phillips, P. S., Woolridge, A and Gillmore, G. K., Time-integrating radon gas measurements in domestic premises: comparison of short-, medium- and long-term exposures. Journal of Environmental Radioactivity, 86(1), 92109, 2006.

Gunby, J. A., Darby, S. C., Miles, J. C. H., Green, B. M. R. and Cox, D. R., Factors affecting indoor radon concentrations in the United Kingdom. Health Physics, 64(1), 2-12, 1993.

Gundersen, L. C. S. and Peake, R. T., Radon in the Coastal Plain of Texas, Alabama and New Jersey. In Gates A. E. and Gundersen, L. C. S. (eds. ), Geologic Controls on Radon, Geological Society of America Special Paper 271, 53-64, 1992.

Hall, I., New radon survey of Scotland. Environmental Radon Newsletter, 36, 1, 2003. 
Hande, M. P., Azizova, T. V., Geard, C. R., Burak, L. E., Mitchell, C. R., Khokhryakov, V. F., Vasilenko, E. K. and Brenner, D. J., Past Exposure to Densely Ionizing Radiation Leaves a Unique Permanent Signature in the Genome. The American Journal of Human Genetics, 72, 1162-1170, 2003.

Henshaw, D. L., Eatough, J. P. and Richardson, R. B., Radon as a causative factor in induction of myeloid leukaemia and other cancers. The Lancet, 335, 1008-1012, 1990.

Hogan, J., Experts can't agree on internal radiation risk. New Scientist, 179(2404), 5, 2003.

HPA, Radon and Public Health: Report prepared by the Subgroup on Radon Epidimeology of the Independent Advisory Group on Ionising Radiation. Documents of the Health Protection Agency, UK, 2009.

HPA, Limitation of Human Exposure to Radon. RCE-15. Centre for Radiation, Chemical and Environmental Haxards. Documents of the Health Protection Agency, UK, 2010.

Hyland, R., and Gunn, J., International comparison of cave concentrations identifying the potential alpha radiation risks to British Cave Users. Health Physics, 67, 76-179, 1994.

ICRP, International Commission on Radiological Protection Statement on Radon. ICRP 37, 2-4, 2009.

Ionising Radiations Regulations - Health and Safety Executive (IRR). The Ionising Radiations Regulations. Health and Safety Executive, Statutory Instrument No. 1333, London, HMSO, 1985.

Ionising Radiations Regulations - Health and Safety Executive (IRR). The Ionising Radiations Regulations. Health and Safety Executive, Statutory Instrument No. 3232, London, HMSO, 1999.

Irwin, A., The changing framework of scientific governance. Environment, Science and NGO Activism workshop, $17^{\text {th }}$ June, The Deep, Hull, 2003.

Kendall, G. M., Doses from radon to organs other than the lung. Environmental Radon Newsletter, $23,4,2000$.

Kenny, A. W., Crooks, R. N. and Kerr, J. R. W., Radium, radon and daughter products in certain waters in Great Britain. J. Inst. Water Engineers, 20, 123-133, 1966.

Krewski, D., Lubin, J. H., Alavanja, M., Catalan, V. S., Field, R. W., Klotz, J. B., Letourneau, E. G., Lynch, C. F., Lyon, J. L., Sandler, D. P., Schoenberg, J. B., Steck, D. J., Stolwijk, J. A., Weinberg, C. and Wilcox, H. B. A combined analysis of North American case-control studies of 
residential radon and lung cancer. Journal of Toxicology and Environmental Health: part A, 69(7), 533-597, 2006.

Langroo M. K., Wise K. N., Duggleby J. C. and Kotler L. H., A nation-wide survey of radon and gamma radiation levels in Australian homes. Yallambie, Victoria, Australian Radiation Laboratory, Report ARL/TR090, 1990.

Lao, K. L., Controlling Indoor Radon: Measurement, Mitigation and Prevention. Van Nostrand Reinhold, New York, 1990.

Little, M. P., A dose of the bomb. Measurements of high-energy neutron exposure in Hiroshima validate estimates of the amount of radiation that survivors of the atom bomb received. Can we predict the risks of radiation more reliably? Nature, 234, 495, 2003.

Lubin, J. H., Boice, J. D., Edling, C., Hornung, R. W., Howe, G. R., Kunz, E., Kusiak, R. A., Morrison, H. I., Radford, E. P. and Samet, J. M., Lung cancer in radon-exposed miners and estimation of risk from indoor exposure. Journal of the National Cancer Institute, 87(11), 817$827,1995$.

Lubin, J. H. and Boice, J. D., Lung cancer risk from residential radon: Meta-analysis of eight epidemiologocal studies. Journal of the National Cancer Institute, 89, 49-57, 1997.

Lubin, J.H., Tomášek, L., Eding, C., Hornung, R.W., Howe, G., Kunz, E., Kusiak, R.A., Morrison, H.I., Radford, E.P., Samet, J.M., Tirmarche, M., Woodward, A., Yao, S.X., Estimating lung cancer mortality from residential radon using data for low exposures of miners. Radiation Research, 147, 126-134, 1997.

Lucie, N. P., Radon exposure and Leukaemia, The Lancet, 2, 99-100, 1989.

Marley, F., Radon, progeny and health: investigation in different environments in Northamptonshire. Unpublished PhD thesis, University of Leicester, 2001.

McLaughlin, J. P., Communicating radon risks to the public and to other Stakeholders. European Radon Research and Industry Collaboration Concerted Action (ERRICCA 2), $3^{\text {rd }}$ European Radon Forum, 19-20 ${ }^{\text {th }}$ May, Geological Survey of Ireland, Dublin, 2003.

Miles, J. C. H., Green, B. M. R., Lomas, P. R. and Cliff, J. D., Radon affected areas: Cornwall and Devon. Documents of the NRPB, 1(1), 35-43, 1990.

Miles, J., Mapping radon-prone areas by lognormal modelling of house radon data. Health Physics, 74(3), 370-378, 1998. 
Miles, J., A new joint approach to radon mapping. European Radon Research and Industry Collaboration Concerted Action (ERRICCA 2), $3^{\text {rd }}$ European Radon Forum, 19-20 $0^{\text {th }}$ May, Geological Survey of Ireland, Dublin, 2003a.

Miles, J., Personal Communication. 2003b.

Muir, H., Too hot to handle: Nurses are spending too much time with some of their patients. New Scientist, 172(2329), 15, 2001.

NRPB, Board statement on radon in homes: human exposure to radon in homes. Documents of the $N R P B$ 1, issue 1, 1990.

Organo, C., Ellard, A., Fenton, D., Synott, H., O’Colmain, M., Prenter, S., O’Reilly, S. and Colgan, P. A. High radon concentrations in a house near Castleisland, County Kerry (Ireland) identification, remediation and post-remediation. Journal of Radiological Protection, 24(2), 107-120, 2004

Papworth, D. S., A need to reduce the radon gas hazard in the UK. Journal Royal Society of Health, 117(2), 75-80, 1997.

Papworth, D. S., Personal Communication. 2005.

Peart, R. J., Cuss, R. J., Beamish, D. and Jones, D. G., Eye in the Sky. High Resolution Airborne Geophysics can help locate and map potential environmental hazards in the UK. Geoscientist, 13(7), 4-7, 2003.

Phillips, P. S., A remarkable story. In: The Radon Manual ( $2^{\text {nd }}$ ed. ) A guide to the requirements for the detection and measurement of natural radon levels, associated remedial measures and subsequent monitoring of results (1. 1-1. 36), Shepperton, Middlesex, The Radon Council Ltd., 1995.

Phillips, P. S., Denman, A. R., Gillmore, G. and Gronow, B., University partnerships for exchange of environmental management expertise: radon in schools programmes in England and Poland. Environmental and Waste Management, 3(1), 11-19, 2000.

Pinel, J., Fearn, T., Darby, S. C. and Miles, J. C. H., Seasonal correction factors for indoor radon measurements in the United Kingdom. Radiation Protection Dosimetry, 58(2), 127-132, 1995.

Rama and Moore, W. S., Mechanism of transport of U-Th series radioisotopes from solid into water. Geochimica et Cosmochimica Acta, 48, 395-399, 1984.

Rees, D. M., Bradley, E. J. and Green, B. M. R., Radon in homes in England and Wales: 2010 Data Review. HPA-CRCE-015, Chilton, UK, 2011. 
Rothstein, H., Don't die of Apathy. New Scientist, 178(2398), 27, $2003 \mathrm{a}$.

Rothstein, H., Neglected risk regulation: the institutional attenuation phenomenon. Health, Risk and Society, 5(1), 85-103, $2003 b$.

Samavat, H., High level background radiation areas in Iran. University of Bradford, Unpublished PhD thesis, 2002.

Samavat, H., personal communication, 2002.

Scheib, C., Appleton, J.D., Miles, J.C.H., Hodgkinson, E., Geological Controls on Radon Potential in England, Proceedings of the Geologists' Association, 124, 910-928, 2013.

Simmonds, J., Robinson, C., Phipps, A., Muirhead, C. and Fry, F., Risk of leukaemia and other cancers in Seascale from all sources of ionising radiation exposure, Didcot, HMSO, 1995.

Smith, G., Johnson, C., Browning, T. and Ransom, S., Final Report of the Texas Indoor Radon Survey. Texas Department of Health and Southwest Texas State University / Environmental Protection Agency, Texas, USA, 1994.

Solomon, S.B., Cooper, M.B., O’Brien, R.S., and Wilkinson, L., Radon exposure in a Limestone Cave. Radiation Protection Dosimetry, 45, 171-174, 1992.

Solomon, S.B., Langroo, R., Lyons, R.G., and James, J.M., Radon exposure to tour guides in Australian show caves. Environment International, 22, S409-S413, 1996.

Spear, S., Campaign targets radon risk. Environmental Health News, 15(28), 4, 2000.

Stoop, P., Glastra, P., Hiemestra, Y., de Vries, L. and Lembrechts, J., Results of the Second Dutch National Survey on Radon in Dwellings. National Institute of Public Health and the Environment (RIVM), Bilthoven, The Netherlands, Report No. 610058006, 1998.

Straume, T., Rugel, G., Marchetti, A. A., Rühm, W., Korschinek, G., McAninch, J. E., Carrall, K., Egbert, S., Faestermann, T., Knie, K., Martinelli, R., Walner, A. and Wallne, C., Measuring fast neutrons in Hiroshima at distances relevant to atomic-bomb survivors. Nature, 424, 539-542, 2003.

Strong, J. C., Laidlaw, A. Y. and O'Riordan, M. C., Radon and its daughters in various British mines. NRPB-R39, HMSO, London, 1975.

Synnott, H. and Fenton, D., An evalution of radon reference levels and radon measurement techniques and protocals in European Countries. ERRICCA 2 European Radon Research and Industry Collaboration Concerted Action, Radiological Protection Institute of Ireland, 2005. 
Szerbin, P., Radon concentrations and exposure levels in Hungarian caves. Health Physics, 71, 362369, 1996.

Talbot, D. K., Davis, J. R. and Rainey, M. P., Natural Radioactivity in private water supplies in Devon. DETR/RAS/00. 010, Department of Energy, Transport \& The Regions, London, 2000.

Tellus SW Geophysical Survey Factsheet, British Geological Survey, Natural Environment Research Council, 2pp, 2013.

The Radiation Protection Authorities in Denmark, Finland, Iceland, Norway and Sweden. Naturally Occurring Radioactivity in the Nordic Countries - Recommendations, 2000.

Tomášek, L., Darby, S. C., Swerdlow, A. J., Plaček, V. and Kunz, E., Radon exposure and cancers other than lung cancer among miners in West Bohemia. The Lancet, 341, 919-923, 1993.

Tomášek, L., Kunz, E., Müller, T., Hůlka, V., Heribanová, A., Matzner, J., Plaček, V., Burian, I and Holeček, J., Radon exposure and lung cancer - Czech cohort study on residential radon. The Science of the Total Environment, 272, 43-51, 2001.

UNSCEAR. Sources, Effects and Risks of Ionizing Radiation. United Nations Scientific Committee on the Efects of Atomic Radiation - 1988 Report to the General Assembly, with Annexes, 1988.

UNSCEAR. Sources and Effects of Ionizing Radiations. United Nations Scientific Committee on the Effects of Atomic Radiations Report to the General Assembly, with Annexes, Table 23, p. $72,1993$.

UNSCEAR. UNSCEAR 2006 Report Annex E. Sources-to-Effects Assessment for Radon in Homes and Workplaces. United Nations Scientific Committee on the Effects of Atomic Radiation, 2009.

U. S. Environmental Protection Agency. EPA Assessment of risks from radon in homes. EPA 402R-03-003, US Environmental Protection Agency, Office of Radiation and Indoor Air, Washington D. C., 2003.

Varley, N. R. and Flowers, A. G., Radon and its correlation with some geological features of the south-west of England. Radiation Protection Dosimetry, 77, 171-176, 1992.

Watson, S. J., Jones, A. L., Oatway, W. B. and Hughes, J. S., Ionising Radiation Exposure of the UK Population: UK Review. HPA-RPD-001, Health Protection Agency, Centre for Radiation, Chemical and Environmental Hazards, Oxfordshire, UK, 2005.

Watts, G., Science commentary: Radon blues, British Medical Journal, 330, 226-227, 2005. 
Wertheim, D., Gillmore, G.K., Brown, L., and Petford, N., A new method of imaging particle tracks in Solid State Nuclear Track Detectors, Journal of Microscopy, 237, 1-6, 2009.

Wertheim, D., Gillmore, G.K., Brown, L., and Petford, N., 3-D imaging of particle tracks in solid state nuclear track detectors, Natural Hazards and Earth System Science, 10, 1033-1036, 2010.

World Health Organisation (WHO). Air Quality Guidelines for Europe. 23, Copenhagen, 1988.

World Health Organisation (WHO). WHO Handbook on Indoor Radon: A Public Health Perspective. World Health Organisation (WHO), Geneva, 2009.

Wichmann, H. E., Heinrich, J., Gerken, M., Kreuzer, M., Wellman, J., Keller, G. and Kreienbrock, L., Domestic radon and lung cancer - current status including new evidence from Germany. In, Burkart, W., Sohrabi, M., Bayer, A. (Eds), High-Levels of Natural Radiation and Radon Areas: Radiation Dose and Health Effects, Elsevier, Amsterdam, 247-252, 2002.

Wilson, D. L., Gammage, R. B., Dudney, C. S. and Saultz, R. J., Summertime elevation of Radon222 levels in Huntsville, Alabama. Health Physics, 60(2), 189-197, 1991.

Wysocka, M., Geophysical methods of supporting radon risk mapping. European Radon Research and Industry Collaboration Concerted Action (ERRICCA 2), $3^{\text {rd }}$ European Radon Forum, 19$20^{\text {th }}$ May, Geological Survey of Ireland, Dublin, 2003.

Wrixon, A. D., Green, B. M. R., Lomas, P. R., Miles, J. C. H., Cliff, K. D., Francis, E. A., Driscoll, C. M. H., James, A. C. and O'Riordan, M. C., Natural Radiation Exposure in UK dwellings. National Radiological Protection Board Report NRPB-R190, 1988.

Zeeb, H. and Shannoun, F. (eds.), WHO Handbook on indoor radon - a public health perspective. World Health Organization. Geneva, 2009.

Zhou H., Suzuki, M., Randers-Pehrson, G., Vannais, D., Chen, G., Trosko, J. E., Waldren, C. A. and Hei, T. K., Radiation risk to low fluences of $\alpha$ particles may be greater than we thought. Proceedings of the National Academy of Sciences, 98(25), 14410-14415, 2001.

Zhou, H., Randers-Pehrson, G., Suzuki, M., Waldren, C. A. and Hei, T. K., Genotoxic damage in non-irradiated cells : contribution from the bystander effect. Radiation Protection Dosimetry, 99(1-4), 227-232, 2002.

Zhou, H., Ivanov, V. N., Gillespie, J., Geard, C. R., Amundson, S. A., Brenner, D. J., Yu, Z., Lieberman, H. W. and Hei, T. K., Mechanism of radiation-induced bystander effect : Role of the cyclooxygenase-2 signalling pathway. Proceedings of the National Academy of Sciences, 102(41), 14641-14646, 2005. 


\section{Table Captions}

\section{Table 1}

Average indoor radon concentrations in $\mathrm{Bq} \mathrm{m}^{-3}$ in selected European countries. Data from Cliff and Gillmore (2001), Stoop et al. (1998), The Radiation Protection Authorities in Denmark, Finland, Iceland, Norway and Sweden (2000), UNSCEAR (1993), Watson et al. (2005), and Dubois (2005). * Non-EU.

\section{Table 2}

US policies and their development together with organisations concerned.

\section{Table 3}

UK (including Northern Ireland) and Republic of Ireland policies and their development together with organisations concerned.

\section{Table 4}

EU policies and their development together with organisations concerned.

\section{Table 5}

Radon policies in a variety of EU and non-EU states (see Colgan and Gutierrez, 1995; Åkerblom, 1999; Phillips et al., 2000, Synott and Fenton, 2005, Zeeb and Shannoun, 2009). * Non-EU.

\section{Table 6}

German policies and their development together with organisations concerned (see Åkerblom, 1999; Synnott and Fenton, 2005).

\section{Table 7}

Swiss policies and their development together with organizations concerned (see Synnott and Fenton, 2005).

\section{Table 8}

Radon potential of different UK building materials based on estimates of radium $\left({ }^{226} \mathrm{Ra}\right)$ concentrations. Phosphogypsum arises as a by-product of the manufacture of phosphate fertilizer. In the UK indoor radon problems are usually the result of radon in the underlying soils/geology rather than from sources in building materials. In Sweden however light-weight alum shale based 
concrete used in properties from 1930 s to 1975 can have a ${ }^{226} \mathrm{Ra}$ concentration as high as $1300 \mathrm{~Bq}$ $\mathrm{kg}^{-1}$. See Cliff and Gillmore (2001).

\section{Table 9}

Indoor radon level building mitigation techniques and Domestic Reduction Factor after Cliff and Gillmore (2001). The Domestic Reduction Factor is based on the average radon level before remediation divided by the average radon concentration after remediation. 


\section{Figure captions}

\section{Figure 1}

Pie chart of natural and human sources of the average annual dose of ionizing radiation received by the population of the USA (data from the National Council on radiation Protection and Measurements USA; see also Gillmore et al., 2002a).

\section{Figure 2}

Radium $^{226}$ decay series. Adapted from Argonne National Laboratory (2005) Figure N.1.

\section{Figure 3}

The general distribution of relatively high uranium concentrations (pink and red) associated with Dinantian Limestones and overlying Namurian Shales in the Peak District. There is considerable variation between uranium concentrations within and between limestone horizons. From Peart et al. (2003) with permission from the British Geological Survey, copyright permit IPR/44-21C.

\section{Figure 4}

The variability in uranium in one Dinantian layer in the Bee Low Limestone Formation in the Peak District. From Peart et al. (2003) with permission from the British Geological Survey, copyright permit IPR/44-21C.

\section{Figure 5.}

The thorium content of the Lower Jurassic Marlstone Rock Formation based on the HiRes-1 survey data (Peart et al., 2003; with permission from the British Geological Survey, copyright permit IPR/44-21C). 

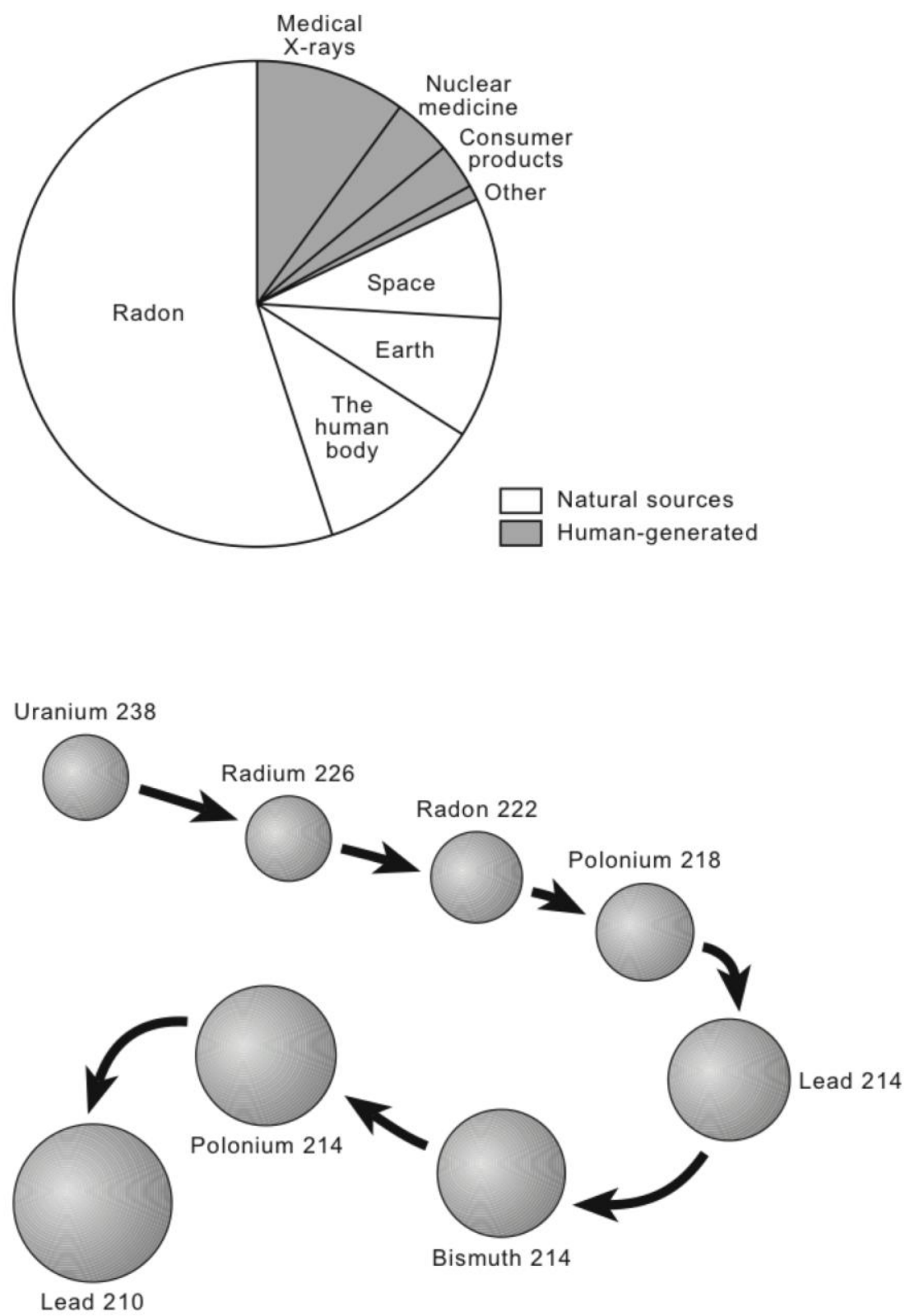

Page 44 of 57 

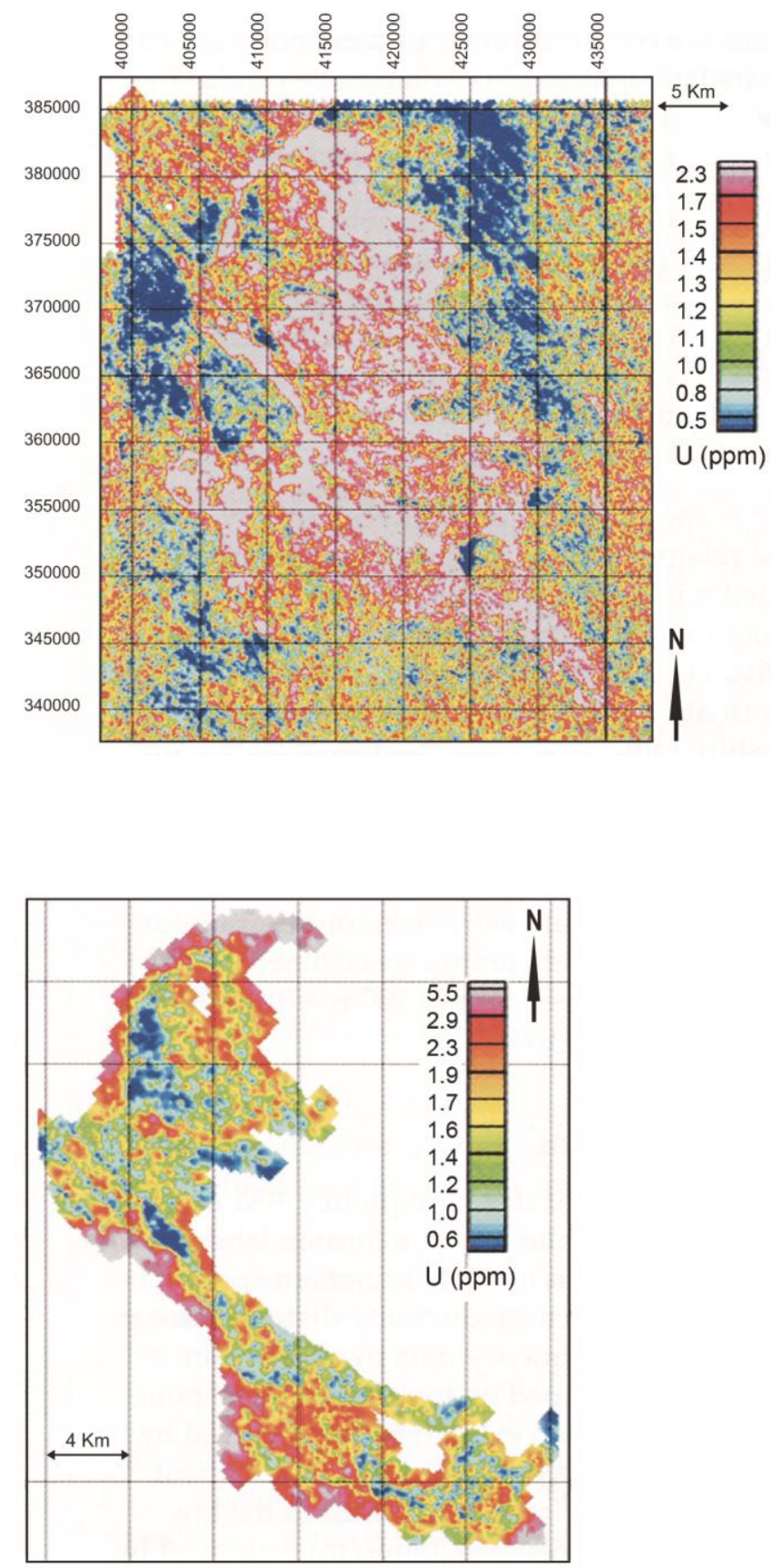


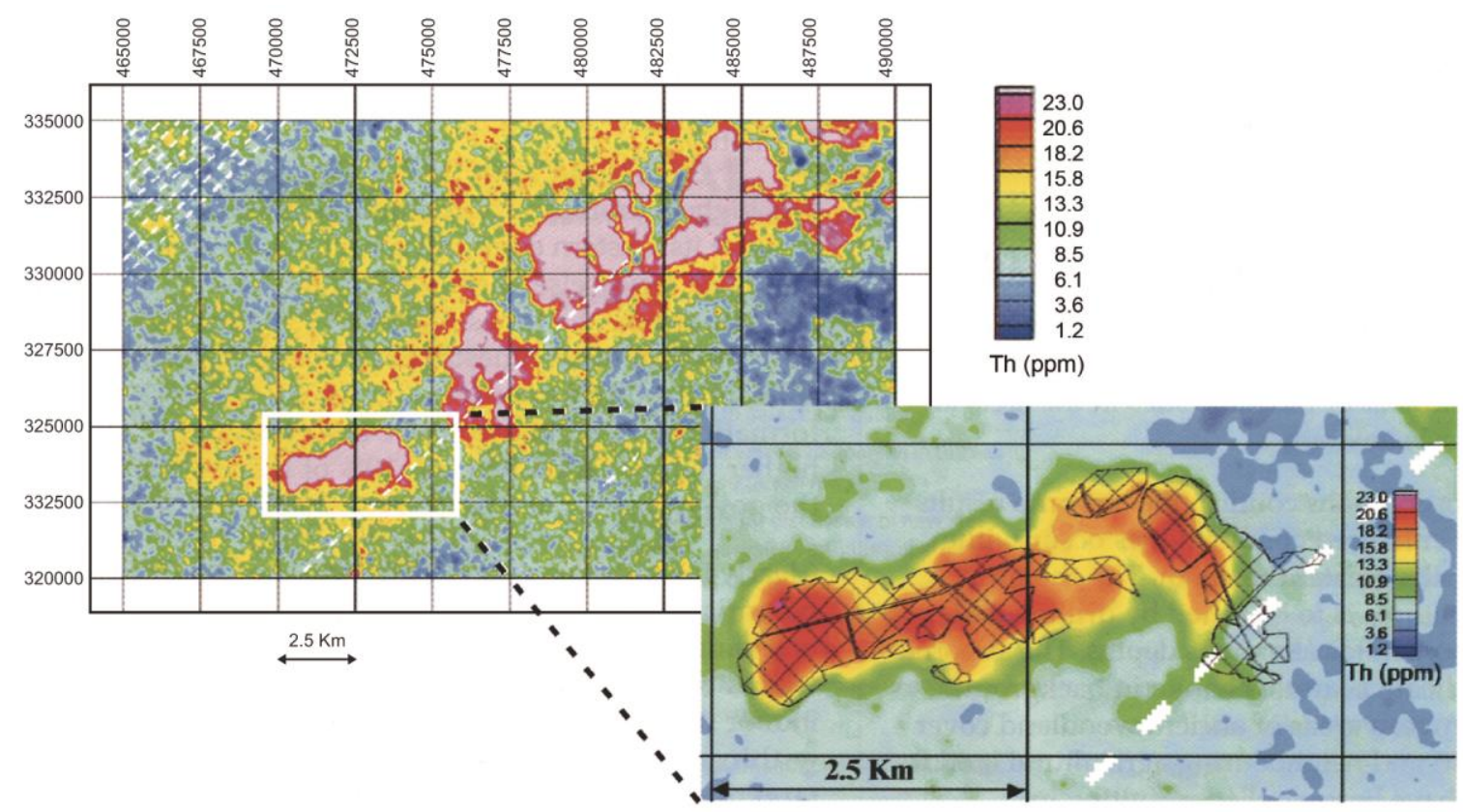


Table 1.

\begin{tabular}{|l|c|c|}
\hline Country & Arithmetic Average & Maximum \\
\hline Denmark & 53 & 1200 \\
\hline Finland & 120 & 33000 \\
\hline France & 63 & 4690 \\
\hline Iceland * NA & NA \\
\hline Italy & 70 & 400 \\
\hline Netherlands & 23 & 65000 \\
\hline Norway $*$ & 89 & 3900 \\
\hline Sweden & 108 & 17000 \\
\hline UK & 20 & \\
\hline
\end{tabular}

Average indoor radon concentrations in $\mathrm{Bq} \mathrm{m}^{-3}$ in selected European countries. Data from Cliff and Gillmore (2001), Stoop et al. (1998), The Radiation Protection Authorities in Denmark, Finland, Iceland, Norway and Sweden (2000), UNSCEAR (1993), Watson et al. (2005) and Dubois (2005). * Not EU. 


\section{USA}

\begin{tabular}{|c|c|c|}
\hline Development & Policies and reference levels & Organisations \\
\hline $\begin{array}{l}\text { - } 19694 \text { WLm limit for uranium miners } \\
\text { - } 1979 \text { action levels for houses in Florida } \\
\text { phosphate mining districts and on tailings in } \\
\text { uranium mining areas in Colorado } \\
\text { - } 1988 \text { Indoor Radon Abatement Act (IRAA) } \\
\text { directed EPA to list and identify areas of the } \\
\text { U.S. with the potential for elevated indoor } \\
\text { radon levels }\end{array}$ & 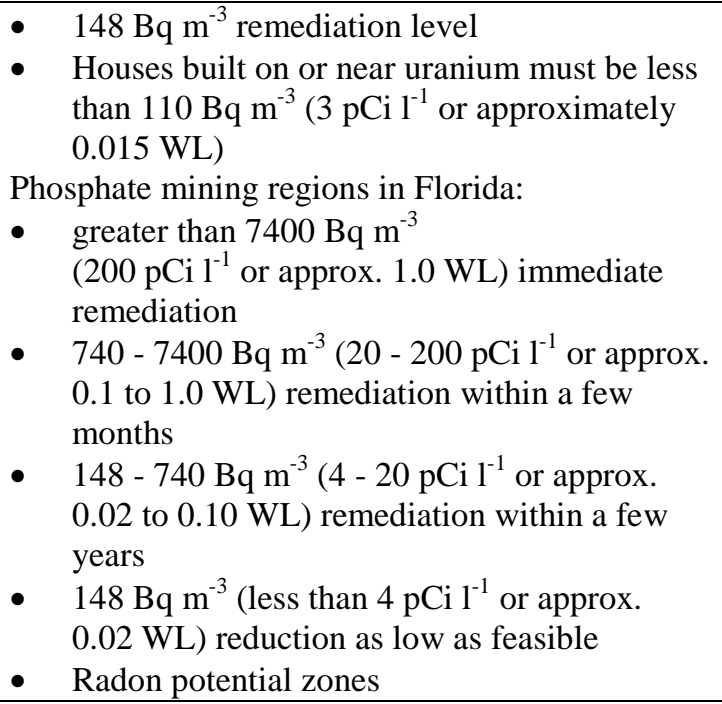 & $\begin{array}{l}\text { U.S. Environmental Protection } \\
\text { Agency (EPA) } \\
\text { National Center for } \\
\text { Environmental Publications } \\
\text { (NSCEP) } \\
\text { www.epa.gov/iaq/radon/ } \\
\text { The National Radon Safety Board } \\
\text { http://www.NRSB.org/ }\end{array}$ \\
\hline
\end{tabular}




\section{United Kingdom and Northern Ireland}

Development
- $\quad$ Late 1980ies measurements of all UK mine by the Health and Safety Executive's Mines Inspectorate

- 1985 Ionising Radiation Regulation (IRR 85) did not include radon in work places

- 1990 Radon Council formed (non profit)

- 1990 declaration of "Radon Affected Areas" Devon and Cornwall

- 1992 declaration of "Radon Affected Area" Northamptonshire

- 1999 Ionising Radiation Regulation (IRR99) including regulations for workplaces

- Average 3-4 $\mathrm{Bq} \mathrm{m}^{-3}$ outdoor, $20 \mathrm{~Bq} \mathrm{~m}^{-3}$ indoor

\section{Policies and reference levels}

$100 \mathrm{~Bq} \mathrm{~m}^{-3}$ target level for dwellings (advisory)

- $\quad 200 \mathrm{~Bq} \mathrm{~m}^{-3}$ enforced level for new dwellings

- $200 \mathrm{~Bq} \mathrm{~m}^{-3}$ action level for existing dwellings (advisory)

- $400 \mathrm{~Bq} \mathrm{~m}^{-3}$ limit for schools an workplaces

- "Controlled Area" (must be designated) if employees ( $>17$ years old) receive $30 \%$ more dose than the limit ( $>6 \mathrm{~m}$ Sv/a)

- "Supervised Area" (designation advisory) if employees receive $10 \%$ more dose than the limit (>1m Sv/a)

- "Radon Affected Areas" = at least 1\% probability of present and future homes above $200 \mathrm{~Bq} \mathrm{~m}^{-3}$
Organisations

National Radiological Protection Board (NRPB),

was part of the Health Protection Agency (HPA),

now part of the Public Health England (PHE)

E-mail: enquiries@phe.gov.uk

The Radon Council

PO Box 39

Shepperton

Middlesex, UK

British

Keyworth

Nottingham,

enquiries@bgs.ac.uk

www.bgs.ac.uk/radon

\section{Republic of Ireland}

Development

- 1991 Radiological Protection Act

- 1992-1999 survey

- 56.000 invitations to households

- measurements in $>11.000$ dwellings

- Most affected areas in south east and large part of Co. Sligo

- 1997 Building Act: preventive measures

- 1998 - 2003 survey radon in all primary and post-primary schools (approx. 4000)

\section{Policies and reference levels}

- $200 \mathrm{~Bq} \mathrm{~m}^{-3}$ reference level

- $150 \mathrm{~Bq} \mathrm{~m}^{-3}$ reference level for school buildings

- $400 \mathrm{~Bq} \mathrm{~m}^{-3}$ reference level for work places

- "High Radon Area" = > 10\% of houses above $200 \mathrm{~Bq} \mathrm{~m}^{-3}$
Organisations

Radiological Protection Institute of

Ireland (RPII)

Dublin 14, Ireland

www.rpii.ie

radon@rpii.ie

UK (including Northern Ireland) and Republic of Ireland policies and their development together with organisations concerned. 


\section{Development}

1957 Euratom contract

21.02.1990 suggestion (90/143/Euratom):

- 1997 enlargement of the Euratom: $3000 \mathrm{~Bq}$ $\mathrm{m}^{-3}$ highest level on work places at $2000 \mathrm{~h}$ work

- $\quad$ EU recommendations for radon in drinking water are in preparation (July 2000)

European Research into Radon in construction Concerted Action (ERRICCA):

- Questionnaire to 42 countries regarding reference levels, regulations or recommendations

Jan. 2002 European Radon Research and Industry Collaboration Concerted Action (ERRICCA 2):

- 3 years (European Commission, BRE)

- $\quad$ scientific and industrial interests on a Europe-wide basis

- European Forum (20 countries) and National Forum
Policies and reference levels

Euratom:

1. New buildings should not exceed $200 \mathrm{~Bq}$ $\mathrm{m}^{-3}$, old buildings not over $400 \mathrm{~Bq} \mathrm{~m}^{-3}$

2. Renovation of buildings exceeding 400 $\mathrm{Bq} \mathrm{m}^{-3}$

3. Identification of "Radon Affected Areas" by the member states

4. Identification of typical building features causing radon transmission, development of renovation measurements

5. Providing information on radon for population, development of building construction avoiding radon

- $1000 \mathrm{~Bq}^{-1}$ recommended action level for private water supplies

- $\quad 500-1000 \mathrm{~Bq} \mathrm{~m}^{-3}$ recommended action level for work places

- $\quad\left(500-1500 \mathrm{~Bq} \mathrm{~m}^{-3}\right.$ recommended action level for work places by the ICRP, 1000

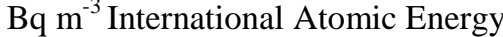

Organisations

European Commission

Environment Directorate-General

Radiation Protection Unit

env-radprot@cec.eu.int

http://europa.eu.int/comm/environment/radprot/index.htm

ICRP - International Commission on Radiological Protection

ICRP SE-171 16 Stockholm

Sweden

Scient.secretary@icrp.org

EU policies and their development together with organizations concerned. 
Table 5

Policies and reference levels 


\begin{tabular}{|c|c|c|}
\hline Albania * & $\begin{array}{l}\text { - } \\
\text { - } \\
\text { - }\end{array}$ & $\begin{array}{l}\text { Geological Survey of Albania } \\
\text { Nuclear Physics Institute }\end{array}$ \\
\hline Australia * & $\begin{array}{l}\text { - } \quad 200 \mathrm{~Bq} \mathrm{~m}^{-3} \text { reference level for dwellings } \\
\text { - } \quad 1000 \mathrm{~Bq} \mathrm{~m}^{-3} \text { reference level for schools and work places }\end{array}$ & $\begin{array}{l}\text { Australasian Radiation Protection Society } \\
\text { arps@21century.com.au }\end{array}$ \\
\hline Belgium & $\begin{array}{l}\text { - } 400 \mathrm{~Bq} \mathrm{~m}^{-3} \text { advisory reference level for existing domestic dwellings } \\
\text { - } \quad \text { No enforced ref level for new buildings } \\
\text { - } \quad \text { Reference level in above ground workplaces } 800 \mathrm{kBq} / \mathrm{m}^{3} \mathrm{~h} / \mathrm{year} \text {. } \\
\text { - } \quad \text { Mapping of risk areas }\end{array}$ & \\
\hline Canada * & $\begin{array}{l}\text { - } 800 \mathrm{~Bq} \mathrm{~m}^{-3} \text { action level for dwellings and schools } \\
\text { - } 150 \mathrm{~Bq} \mathrm{~m}^{-3} \text { target level } \\
\text { - } \quad \text { both levels suggested by the Federal/Provincial Advisory Committee on } \\
\text { Environmental and Occupational Health } \\
\text { - No rate for work places }\end{array}$ & $\begin{array}{l}\text { Canadian Centre for Occupational Health and Safety (CCOHS) } \\
\text { http://www.ccohs.ca } \\
\text { Canadian Institute for Radiation Safety (CAIRS) (Institut } \\
\text { Canadien de Radioprotection) } \\
\text { cairs.info@ cairs.ca }\end{array}$ \\
\hline Denmark & $\begin{array}{l}\text { - } 100 \mathrm{~Bq} \mathrm{~m}^{-3} \text { for new buildings } \\
\text { - } \quad 200 \mathrm{~Bq} \mathrm{~m}^{-3} \text { for simple remedial measures in existing dwellings } \\
\text { - } 400 \mathrm{~Bq} \mathrm{~m}^{-3} \text { for more costly measures in existing buildings } \\
\text { - } \quad 400 \mathrm{~Bq} \mathrm{~m}^{-3} \text { for existing and new workplaces }\end{array}$ & Danish Building Regulations, 2010 \\
\hline Finland & $\begin{array}{l}\text { - } 400 \mathrm{~Bq} \mathrm{~m}^{-3} \text { ref level for existing dwellings } \\
\text { - } 200 \mathrm{~Bq} \mathrm{~m}^{-3} \text { for new dwellings (domestic) } \\
\text { - } 200 \mathrm{~Bq} \mathrm{~m}^{-3} \text { recommended for new school buildings } \\
\text { - } \quad 200 \mathrm{~Bq} \mathrm{~m}^{3} \text { ref level for new workplace buildings } \\
\text { - } \quad 400 \mathrm{~Bq} \mathrm{~m}^{-3} \text { enforced for existing workplaces }\end{array}$ & $\begin{array}{l}\text { STUK - Radiation and Nuclear Safety Authority } \\
\text { http://wWW.stuk.fi }\end{array}$ \\
\hline Greece & $\begin{array}{l}\text { - } 200 \mathrm{~Bq} \mathrm{~m}^{-3} \text { ref level for new buildings (domestic) } \\
\text { - } 400 \mathrm{~Bq} \mathrm{~m}^{-3} \text { for existing domestic buildings } \\
\text { - } \quad 400 \mathrm{~Bq} \mathrm{~m}^{-3} \text { action level for existing work places }\end{array}$ & \\
\hline Italy & $\begin{array}{l}\text { - } 500 \mathrm{~Bq} \mathrm{~m}^{-3} \text { limit for school buildings and work places } \\
\text { - } \quad \text { No rate for dwellings }\end{array}$ & National Institute for Ionising Radiation Metrology (ENEA) \\
\hline Luxembourg & 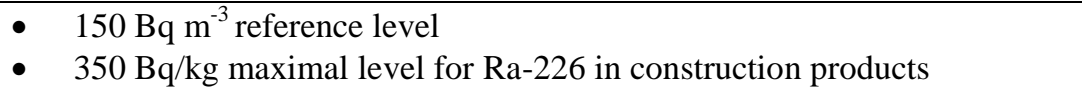 & Centre Universitaire, Division de la Radioprotection \\
\hline
\end{tabular}




\begin{tabular}{|c|c|c|}
\hline Netherlands & - $\quad 20 \mathrm{~Bq} \mathrm{~m}^{-3}$ reference level (1995) & \\
\hline Norway* & $\begin{array}{l}\text { - } \quad 400 \mathrm{~Bq} \mathrm{~m}^{-3} \text { recommended } \\
\text { - } \quad 200 \mathrm{~Bq} \mathrm{~m}^{-3} \text { recommended for new dwellings } \\
\text { - } \quad 400 \mathrm{~Bq} \mathrm{~m}^{-3} \text { limit for schools and work places } \\
\end{array}$ & Norwegian Radiation Protection Authority (NRPA) \\
\hline Poland & $\begin{array}{ll}\text { - } & \text { No reference level for domestic properties } \\
\text { - } & \text { No enforced ref level for existing and new workplaces } \\
\text { - } & \text { No regulation guidelines for buildings } \\
\text { - } & \text { No mapping radon risk areas }\end{array}$ & \\
\hline Romania & $\begin{array}{l}\text { - } \quad \text { No advisory reference level for existing dwellings } \\
\text { - } \quad \text { No enforced ref level for new buildings } \\
\text { - } \quad \text { o enforced reference level for existing / new workplaces } \\
\text { - } \quad \text { Below ground workplace } 1110 \mathrm{~Bq} \mathrm{~m}^{-3} \\
\text { - } \quad \text { No regulation guidelines for buildings } \\
\text { - } \quad \text { No mapping of risk areas }\end{array}$ & \\
\hline Russia * & $\begin{array}{l}\text { - } 400 \mathrm{~Bq} \mathrm{~m}^{-3} \text { enforced reference level for existing dwellings (>200 } \mathrm{Bq} \mathrm{m}^{-3} \\
\text { for simple mitigation, }>400 \mathrm{~Bq} \mathrm{~m}^{-3} \text { upper action level) } \\
\text { - } 200 \mathrm{~Bq} \mathrm{~m}^{-3} \text { enforced for new dwellings }\end{array}$ & \\
\hline Slovenia & $\begin{array}{l}\text { - } \quad 400 \mathrm{~Bq} \mathrm{~m}^{-3} \text { domestic dwellings } \\
\text { - } \quad 1000 \mathrm{~Bq} \mathrm{~m}^{-3} \text { for work places }\end{array}$ & \\
\hline Sweden & $\begin{array}{ll}\text { - } & \text { Advisory level } 200 \mathrm{~Bq} \mathrm{~m}^{-3} \text { for existing dwellings } \\
\text { - } & \text { Enforced level } 400 \mathrm{~Bq} \mathrm{~m}^{-3} \text {, for existing dwellings } \\
\text { - } & 400 \mathrm{~Bq} \mathrm{~m}^{-3} \text { ref level for existing workplaces above ground } \\
\text { - } & 2500 \mathrm{kBq} \mathrm{m}^{-3} \mathrm{~h} \text { per year for below ground workplaces }\end{array}$ & $\begin{array}{l}\text { Statens Strålskyddinstitut (Swedish Radiation Protection } \\
\text { Insitute) }\end{array}$ \\
\hline $\begin{array}{l}\text { World Health } \\
\text { Oganization }\end{array}$ & - Advisory level $100 \mathrm{~Bq} \mathrm{~m}^{-3}$ for indoor air & World Health Organization \\
\hline
\end{tabular}

Radon policies in a variety of EU and non-EU states (see Åkerblom, 1999; Phillips et al., 2000; Synott and Fenton, 2005; Zeeb and Shannoun, 2009). * Non EU. 
Table 6

Germany

Development

Policies and reference levels

- $\quad$ Since 1980s measures of 50,000

dwellings

- 7500 sampled houses 1982 -1991 (3 months) and 1991-1993 (1 year): Average radon $50 \mathrm{~Bq} \mathrm{~m}^{-3}$ with peaks of several 10,000

- $\quad$ Supporting renovation of high affected dwellings

- $\quad$ Since 1994 controlling radon in waterworks

- $200 \mathrm{~Bq} \mathrm{~m}^{-3}$ recommended for new

Bundesministerium für Umwelt, Naturschutz und houses

- $400 \mathrm{~Bq} \mathrm{~m}^{-3}$ for existing domestic buildings

- $100 \mathrm{~Bq} \mathrm{~m}^{-3}$ under discussion

- Reference level of $2000 \mathrm{kBq} \mathrm{m}^{-3} \mathrm{~h}$ with a limit of $6000 \mathrm{kBq} \mathrm{m}^{-3} \mathrm{~h}$ for waterworks and radon spas

- Map of radon potential by geology

Reaktorsicherheit (BMU)

www.bmu.de

Bundesamt fuer Strahlenschutz, Federal Agency for Radiation Protection

www.bfs.de

SSK - Strahlenschutzkommission, Radiation Protection

Commission at the Federal Agency for Radiation

Protection

HHeller@bfs.de

Swiss authority for health

- Radiation Protection Ordinance -

Strahlenschutzverordnung (StrlSchV), in force since 2001

WWW.Ssk.de

German policies and their development together with organisations concerned (see Åkerblom, 1999; Synnott and Fenton, 2005) 
Table 7

\section{Switzerland}

\section{Development}

- 1991-1990 first measurements in the Canton of Basel City

- measurements by Cantons with financial support by the Federal Health Agency
Policies and reference levels

- $1000 \mathrm{~Bq} \mathrm{~m}^{-3}$ compulsory reference level in domestic environments

- $400 \mathrm{~Bq} \mathrm{~m}^{-3}$ recommended rate for new and renovated buildings

- $3000 \mathrm{~Bq} \mathrm{~m}^{-3}$ limit work places

- Radon affected areas: dwellings $>200 \mathrm{~Bq} \mathrm{~m}^{-3}$, cellars > $1000 \mathrm{~Bq} \mathrm{~m}^{-3}$

- $\quad$ Radon area $=$ arithmetic median $>200 \mathrm{~Bq} \mathrm{~m}^{-3}$ or single values $>1000 \mathrm{~Bq} \mathrm{~m}^{-3}$
Organisations

Bundesamt fuer Gesundheit, Federal Health

Agency

Abteilung Strahlenschutz, Office for radiation

protections, radon and waste

Bundesamt fuer Gesundheit, Federal Health

Sektion Ueberwachung der Radioaktivitaet,

Division for assessing radioactive risk

Swiss policies and their development together with organizations concerned (see Synnott and Fenton, 2005). 
Table 8

\begin{tabular}{|l|c|}
\hline Material & $\begin{array}{l}\text { Radium concentration } \\
\mathrm{Bq} \mathrm{kg}^{-1}\end{array}$ \\
\hline Clay bricks & 52.0 \\
\hline Gravel aggregate & 7.4 \\
\hline Flint aggregate & 2.2 \\
\hline Granite aggregate bricks & 11.0 \\
\hline Granite bricks & 89.0 \\
\hline Phosphogypsum & 120.0 \\
\hline Natural gypsum & 23.0 \\
\hline Concrete block with fly ash & 65.0 \\
\hline Aerated concrete & 89.0 \\
\hline Vermiculite & 93.0 \\
\hline
\end{tabular}

Radon potential of different UK building materials based on estimates of radium $\left({ }^{226} \mathrm{Ra}\right)$ concentrations. Phosphogypsum arises as a by-product of the manufacture of phosphate

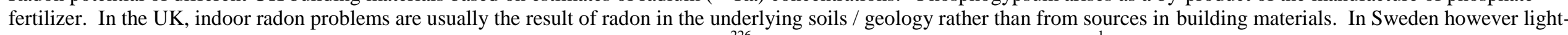
weight alum shale based concrete used in properties from 1930s to 1975 can have a ${ }^{226}$ Ra concentration as high as $1300 \mathrm{~Bq} \mathrm{~kg}^{-1}$. See Cliff and Gillmore (2001). 
Table 9

\begin{tabular}{|c|c|c|}
\hline Method & $\begin{array}{l}\text { Domestic } \\
\text { Reduction } \\
\text { Factor }\end{array}$ & Comments \\
\hline Sealing cracks & $2-3$ & $\begin{array}{l}\text { Types of sealants are:- } \\
\text { - } \quad \text { Polymer-modified cement mortars. } \\
\text { - } \quad \text { Silicone sealants. } \\
\text { - } \quad \text { Acrylic sealants. } \\
\text { - } \quad \text { Expanding polyurethane sealants. } \\
\text { - } \quad \text { Plastic sheeting. }\end{array}$ \\
\hline $\begin{array}{l}\text { Altering ventilation inside } \\
\text { building }\end{array}$ & $2-3$ & $\begin{array}{l}\text { Natural ventilation reduces radon concentrations by:- } \\
\text { - Dilution by mixing low-radon air from outdoors with room air. } \\
\text { - } \quad \text { Reduction in pressure differences between outdoor air and indoor air at } \\
\text { lowest floor level. }\end{array}$ \\
\hline $\begin{array}{l}\text { Additional or improvement of } \\
\text { sub-floor ventilation }\end{array}$ & $2-3$ & $\begin{array}{l}\text { Works by diluting and transporting radon away from beneath the floor. } \\
\text { Main requirements:- } \\
\text { - Airbricks opposite sides of the under-floor void. } \\
\text { - Suitable strategy for radon levels up to } 500 \mathrm{~Bq} \mathrm{~m}^{-3} \text { for natural } \\
\text { ventilation. } \\
\text { - If fan assisted under-floor ventilation - suitable for about } 900 \mathrm{~Bq} \mathrm{~m}^{-3} \text {. }\end{array}$ \\
\hline $\begin{array}{l}\text { Installing a positive } \\
\text { pressurization system }\end{array}$ & $3-4$ & $\begin{array}{l}\text { A small fan which pumps filtered air into a building from either outside or } \\
\text { loft space. By reducing the pressure gradient across the ground floor, } \\
\text { reduce the force driving radon from underlying soil. } \\
\text { Reduces indoor radon by dilution and displacement. }\end{array}$ \\
\hline Installing radon sumps & $8-16$ & $\begin{array}{l}\text { Three main designs of sump systems:- } \\
\text { - Internal with internal pipework. } \\
\text { - Internal with external pipework. } \\
\text { - } \quad \text { Externally excavated. }\end{array}$ \\
\hline
\end{tabular}

Indoor radon level building mitigation techniques and Domestic Reduction Factor after Cliff and Gillmore (2001). The Domestic Reduction Factor is based on the average radon level before remediation divided by the average radon concentration after remediation. 